\title{
Potential for Subsidence at the Low-Level Radioactive Waste Disposal Area
}

K. N. Keck

R. R. Seitz

September 2002

Idaho National Engineering and Environmental Laboratory Bechtel BWXT Idaho, LLC 


\title{
Potential for Subsidence at the Low-Level Radioactive Waste Disposal Area
}

\author{
Karen N. Keck \\ Roger R. Seitz
}

September 2002

Idaho National Engineering and Environmental Laboratory Idaho Falls, Idaho 83415

Prepared for the

U.S. Department of Energy

Assistant Secretary for Environmental Management

Under DOE Idaho Operations Office

Contract DE-AC07-99ID13727 


\begin{abstract}
U.S. Department of Energy (DOE) Order 435.1, Radioactive Waste Management requires that DOE low-level radioactive waste (LLW) disposal facilities receive a Disposal Authorization Statement (DAS) from DOEHeadquarters. The DAS for the LLW disposal facility at the Radioactive Waste Management Complex (RWMC) at the Idaho National Engineering and Environmental Laboratory (INEEL) was granted in April 2000 and included a number of conditions that must be addressed. A maintenance plan (Schuman 2000) was prepared that identifies the tasks to be completed to address the conditions in the DAS as well as a schedule for their completion. The need for a subsidence analysis was one of the conditions identified for the DAS, and thus, a task to prepare a subsidence analysis was included in the maintenance plan. This document provides the information necessary to satisfy that requirement.
\end{abstract}




\section{EXECUTIVE SUMMARY}

U.S. Department of Energy (DOE) Order 435.1, Radioactive Waste Management requires that DOE low-level radioactive waste (LLW) disposal facilities receive a Disposal Authorization Statement (DAS) from DOE-Headquarters. The DAS for the LLW disposal facility at the Radioactive Waste Management Complex (RWMC) at the Idaho National Engineering and Environmental Laboratory (INEEL) was granted in April 2000 and included a number of conditions that must be addressed. A maintenance plan (Schuman 2000) was prepared that identifies the tasks to be completed to address the conditions in the DAS as well as a schedule for their completion. The need for a subsidence analysis was one of the conditions identified for the DAS, and thus, a task to prepare a subsidence analysis was included in the maintenance plan. This document provides the information necessary to satisfy that requirement.

A site-specific performance assessment (PA) and composite analysis (CA) are critical parts of the documentation forming the basis for the DAS. The PA and CA estimate the potential impacts of the disposed waste on human health and safety, and provide information regarding disposal operations, facility design, and closure required to ensure that potential risks are maintained at acceptable levels. The PA focuses on the wastes placed in the active LLW disposal facility, so that design and operational controls may be established to ensure that performance objectives will be met. The CA provides a reasonably conservative assessment of the cumulative impacts from the active LLW disposal facility and all other sources of radioactive contamination that could interact with releases from the LLW disposal facility. The RWMC PA (Case et al., 2000) and CA (McCarthy et al., 2000) were completed and approved by DOE-ID. The documents were then submitted to the DOE-Headquarters Low-Level Waste Disposal Facility Federal Review Group (LFRG) in September 2000.

LLW disposal facility design constraints are established based on the results of the PA and CA and the ability to meet the design constraints could be influenced by subsidence. For example, design constraints from the PA and CA that may be influenced by subsidence include:

- the need to maintain a long-term average infiltration rate of less than or equal to $1 \mathrm{~cm} / \mathrm{yr}$, and

- the need to maintain a final cover thickness of at least $2.4 \mathrm{~m}(8 \mathrm{ft})$ over the waste in the pits and $3.3 \mathrm{~m}(10 \mathrm{ft})$ over the soil vaults.

Thus, the LFRG considered it important to address the potential for subsidence at the RWMC Subsurface Disposal Area (SDA) LLW disposal facility in the context of the DAS.

The LLW disposal facility at the RWMC is somewhat unique in the fact that it is located within Comprehensive Environmental Response, Compensation and Liability Act (CERCLA) Operable Unit 7 $13 / 14$, which is currently in the remedial investigation/feasibility study (RI/FS) phase. It has been determined that the LLW disposal facility will be closed under the remedial action specified in the record of decision (ROD) for CERCLA Operable Unit 7-13/14. This ROD is currently planned for release in the year 2007, which has recently been rescheduled from 2003. Since the facility will be closed under CERCLA, DOE Order 435.1 requirements will be applied until the end of operations and CERCLA requirements will apply thereafter. Thus, this report is an important link between the operational requirements for the disposal facility and the final closure of the facility under the CERCLA process, because the potential for subsidence will need to be an important consideration as part of the RI/FS.

Landfill subsidence is the differential settling of waste and or soil from an initial elevation to a lower elevation. Landfill subsidence results from primary consolidation and secondary compression of the 
waste mass, and from collapse of voids or cavities in the fill and around containers by corrosion, oxidation, or biochemical decay of waste materials. The potential for subsidence at the SDA LLW disposal facility is best determined by reviewing past and current disposal practices and development of theoretical and empirical predictions based on past observed subsidence in the SDA.

Nineteen years of SDA monthly inspection records from 1983 to 2002 were reviewed. Over 160 subsidences were recorded during this period, both in field logs and in photos. In most cases, the inspector reported the length, width, maximum depth and average depth, and the date of the observation. The observed maximum and average subsidence depth values are $3.7 \mathrm{~m}$ and $0.6 \mathrm{~m} \mathrm{(12} \mathrm{and} 2 \mathrm{ft})$,

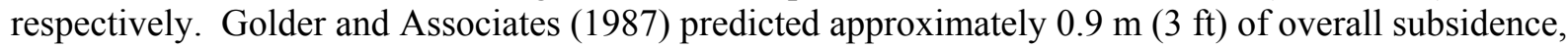
which is similar to the observed subsidences. The EPA (1987) determined that the expected subsidence of Resource Conservation and Recovery Act landfill cover from soil consolidation and container failure would be approximately $20 \%$ of the total landfill thickness.

The SDA has a significant risk of future subsidence events that must be considered as part of any final closure concept. Many differential settlements of sufficient area and depth to damage a final closure cover have been observed. The most severe differential settlements appear to occur within 10 years of closure of the disposal unit; however, many exceptions to this trend have been reported. Most subsidence in pits and soil vaults closed after 1984 should occur before final closure in 2012. However, some subsidence will continue to occur after that time. Disposal units closed after 2002 would likely present the greatest subsidence risks to a final closure cover. These units include the active LLW disposal pits $18-20$. 


\section{CONTENTS}

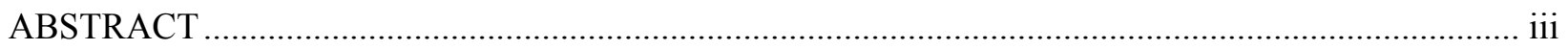

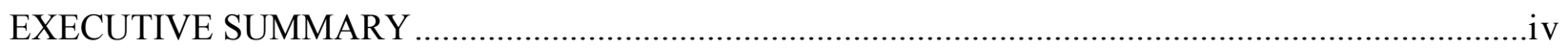

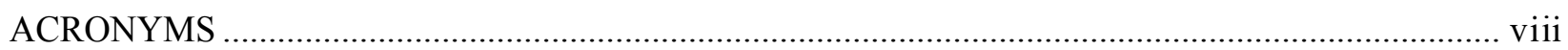

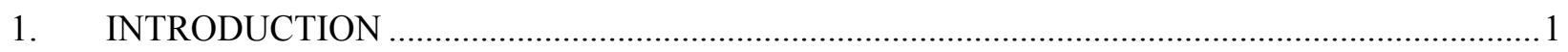

1.1 Closure Constraints under DOE Order 435.1 ............................................................... 1

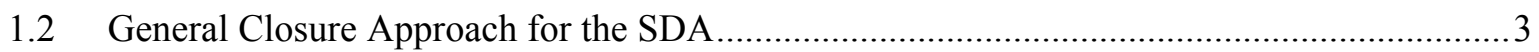

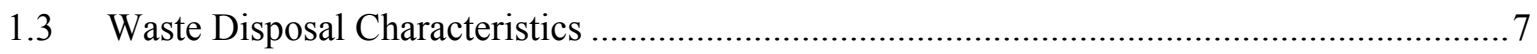

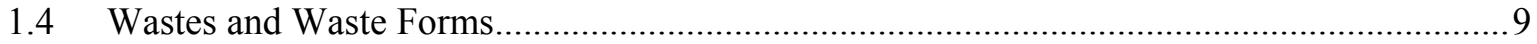

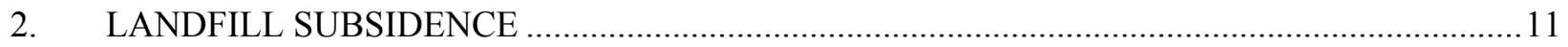

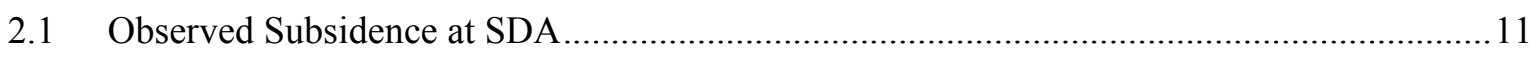

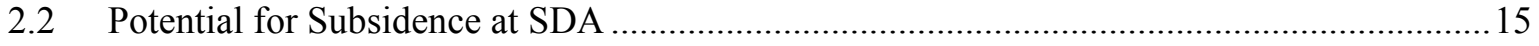

3. SUBSIDENCE CONSIDERATIONS FOR FINAL CLOSURE ...............................................17

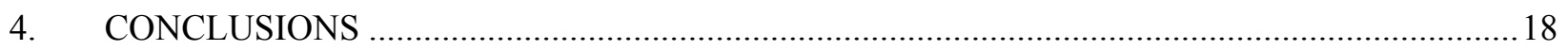

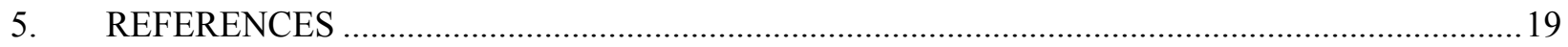

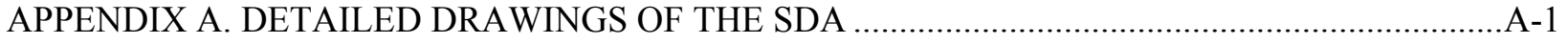

APPENDIX B. DRAWINGS OF THE CONCRETE VAULTS …......................................................

APPENDIX C. SELECTED PHOTOS OF RWMC SDA SUBSIDENCE FEATURES..........................

\section{FIGURES}

Figure 1. RWMC and its location (Photo is rotated with north to the left) ............................................2

Figure 2. Facilities at the RWMC, including the active LLW disposal pits and soil vault rows. ............... 8

Figure 3. Photo of currently operating LLW disposal pits within the SDA...........................................8

\section{TABLES}

Table 1. Physical properties data for soil sampled from Spreading Area B (adapted from Binda 1981).....4 
Table 2. Soil sample classification and hydraulic properties data for potential on-Site borrow areas (Smith et al. 1994).

Table 3. Summary statistics for Subsurface Disposal Area subsidence features observed from 1983 to 1997.

Table 4. Subsidence data collected from 1996 to 2002 for the Subsurface Disposal Area.. 


\section{ACRONYMS}

CA composite analysis

CERCLA Comprehensive Environmental Response, Compensation, and Liability Act

DAS Disposal Authorization Statement

DOE Department of Energy

EBTF Engineered Barriers Test Facility

INEEL Idaho National Engineering and Environmental Laboratory

LFRG Low-level Waste Disposal Facility Federal Review Group

LLW low-level radioactive waste

PA performance assessment

RCRA Resource Conservation and Recovery Act

RI/FS Remedial Investigation/Feasibility Study

ROD Record of Decision

RWMC Radioactive Waste Management Complex

RRWAC reusable property, recyclable materials, and waste acceptance criteria

SDA Subsurface Disposal Area

SVR soil vault row

WROC Waste Reduction Operations Complex 


\section{INTRODUCTION}

The Idaho National Engineering and Environmental Laboratory (INEEL) Site occupies roughly 230,600 ha (570,00 acres) of mostly undeveloped, high desert terrain in southeast Idaho (see Figure 1). The Radioactive Waste Management Complex (RWMC) located in the southwestern quadrant of the INEEL encompasses a total of 70 ha $(174$ acres $)$ and has been used for waste disposal operations since the late 1950's. The RWMC is divided into three separate areas by function: the Subsurface Disposal Area (SDA), the Transuranic Storage Area, and the Operations and Administrative Area. The active low-level radioactive waste (LLW) disposal facility is located near the east end of the SDA (see Appendix A). LLW disposal operations at the active pits and vaults in the SDA are expected to continue through the year 2009 and must comply with requirements of U.S. Department of Energy (DOE) Order 435.1, Radioactive Waste Management (DOE 1999).

Two to four thousand cubic meters of contact-handled LLW and roughly 100 cubic meters of remote-handled LLW from generators throughout the INEEL are disposed annually in the active pits. Annual volumes disposed vary from year to year depending on programmatic needs. Contact-handled LLW and some remote-handled LLW are disposed in an open pit roughly $9 \mathrm{~m}(30 \mathrm{ft})$ deep covering an area of roughly 3.14 ha (7.76 acres). Specially designed, cylindrical concrete vaults are used for disposal of most of the remote-handled LLW (see Appendix B). The cylinders are covered by thick concrete shielding plugs, which are then covered with soil. From 1984 to 1993, remote-handled LLW was disposed in soil vaults located in the SDA, but outside the current LLW disposal area. These soil vaults comprised holes bored in the existing soil.

The LLW disposal facility is somewhat unique in the fact that it is located within Comprehensive Environmental Response, Compensation and Liability Act (CERCLA) Operable Unit 7-13/14, which is currently in the remedial investigation/feasibility study (RI/FS) phase. It has been determined that the LLW disposal facility will be closed under the remedial action specified in the record of decision (ROD) for CERCLA Operable Unit 7-13/14. This ROD is currently planned for release in the year 2007, which was recently rescheduled from previous plans for completion in 2003. Since the facility will be closed under CERCLA, DOE Order 435.1 requirements will be applied until the end of operations and CERCLA requirements will apply thereafter. Nevertheless, DOE requirements will be considered in the course of the CERCLA RI/FS.

\subsection{Closure Constraints under DOE Order 435.1}

DOE Order 435.1 requires that DOE LLW disposal facilities receive a Disposal Authorization Statement (DAS) from DOE-Headquarters. The DAS for the LLW disposal facility at the RWMC was granted in April 2000 and included a number of conditions that must be addressed. A maintenance plan (Schuman 2000) was prepared that identifies the tasks to be completed to address the conditions in the DAS as well as a schedule for their completion. The need for a subsidence analysis was one of the conditions identified for the DAS. Thus, a task to prepare a subsidence analysis was included in the maintenance plan. This document provides the information necessary to satisfy that requirement.

A site-specific performance assessment (PA) and composite analysis (CA) are critical parts of the documentation forming the basis for the DAS. These assessments and analyses estimate the potential impacts of the disposed waste on human health and safety, and provide information regarding disposal

operations, facility design, and closure required to ensure that potential risks are maintained at acceptable levels. The PA focuses on the wastes placed in the active LLW disposal facility, so that design and operational controls may be established to ensure that performance objectives will be met. The CA 

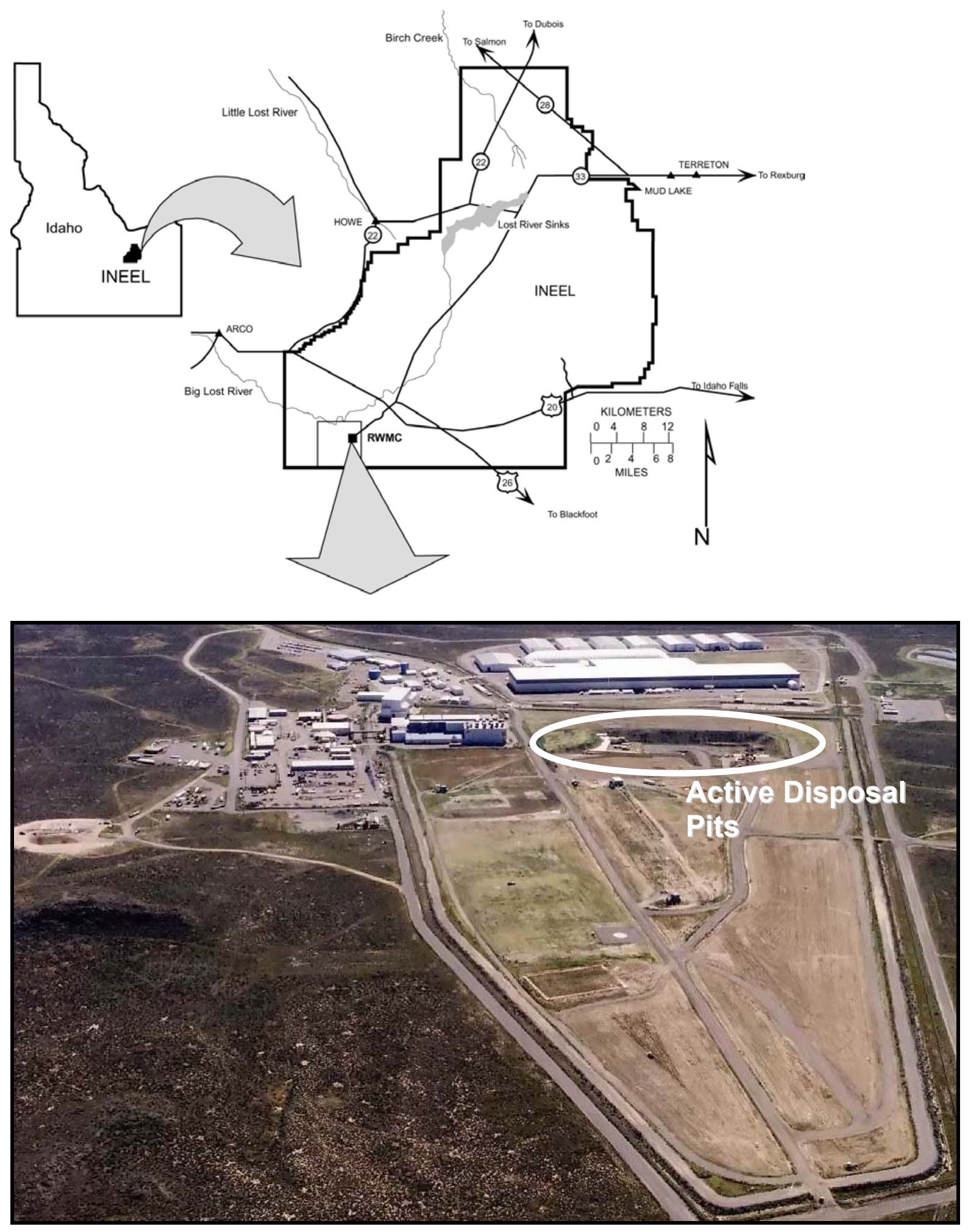

Figure 1. RWMC and its location (Photo is rotated with north to the left). 
provides a reasonably conservative assessment of the cumulative impacts from the active LLW disposal facility and all other sources of radioactive contamination that could interact with releases from the LLW disposal facility. The RWMC PA (Case et al., 2000) and CA (McCarthy et al., 2000) were completed and approved by DOE-ID. The documents were then submitted to the DOE-Headquarters Low-Level Waste Disposal Facility Federal Review Group (LFRG) in September 2000.

Disposal facility design constraints are established based on the results of the PA and CA and the ability to meet the design constraints could be influenced by subsidence. For example, design constraints from the PA and CA that may be influenced by subsidence include:

- the need to maintain a long-term average infiltration rate of less than or equal to $1 \mathrm{~cm} / \mathrm{yr}$, and

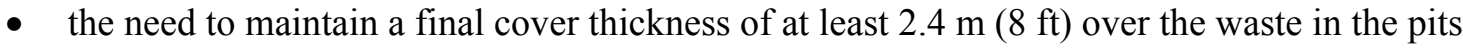
and $3.3 \mathrm{~m}(10 \mathrm{ft})$ over the soil vaults.

Thus, the LFRG considered it important to address the potential for subsidence at the SDA in the context of the DAS.

\subsection{General Closure Approach for the SDA}

Closure of the active LLW disposal pits will be conducted in two stages (Seitz et al. 2001). Interim closure is conducted roughly on an annual basis as waste is placed in the active pits. As discussed previously, the final closure concept will be determined through the CERCLA process, which is currently in the RI/FS stage, and will be implemented as specified in the resulting ROD. A general discussion of interim and final closure is provided in the following paragraphs.

A preliminary closure plan for the active LLW disposal area has been developed (Seitz et al.

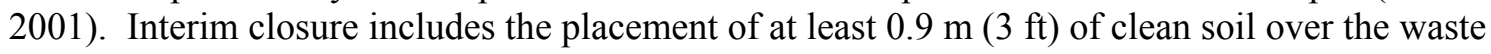
packages. In most cases, the interim cover over waste in the pits is much thicker than $0.9 \mathrm{~m}(3 \mathrm{ft})$. A summary of the properties of these soils is provided in Tables 1 and 2. These soils are rated as "slightly to moderately" susceptible to subsidence. The interim cover is spread over the waste and contoured, and then seeded with grasses to promote evapotranspiration and limit potential erosion. Placement, compaction and contouring of the interim cover for drainage is controlled as a maintenance related task.

In the case of the concrete vaults, the interim cover is assumed to include the approximately 1.2 $\mathrm{m}(4 \mathrm{ft})$ reinforced concrete shielding plug. To inhibit moisture infiltration into the vaults, the seams between adjacent plug caps of filled vaults are sealed with acrylic caulk at the surface of the vault array and a silicone sealant is placed at the interface between the vault plug and the vault wall. Soil cover of at least $0.9 \mathrm{~m}$ is added as each row of vaults is filled. According to RWMC personnel, more than $0.9 \mathrm{~m}(3 \mathrm{ft})$ of soil is typically placed over the vaults. Most vaults have at least $1.8 \mathrm{~m}(6 \mathrm{ft})$ of soil cover.

The interim cover is actively maintained throughout the SDA to repair subsidence. Surface water is controlled via dikes and a system of surface drainage ditches. Installation of the interim cover in the active LLW disposal area is performed roughly once a year with the actual time frame based on the rate of waste disposal and other operational considerations.

The preliminary closure plan for the active LLW disposal area (Keck and Bhatt 1996) describes some specific choices for closure cover designs at the SDA based on the waste types, waste forms, facility location, site hydrogeologic properties, and exposure scenarios considered in the PA and lessons learned 


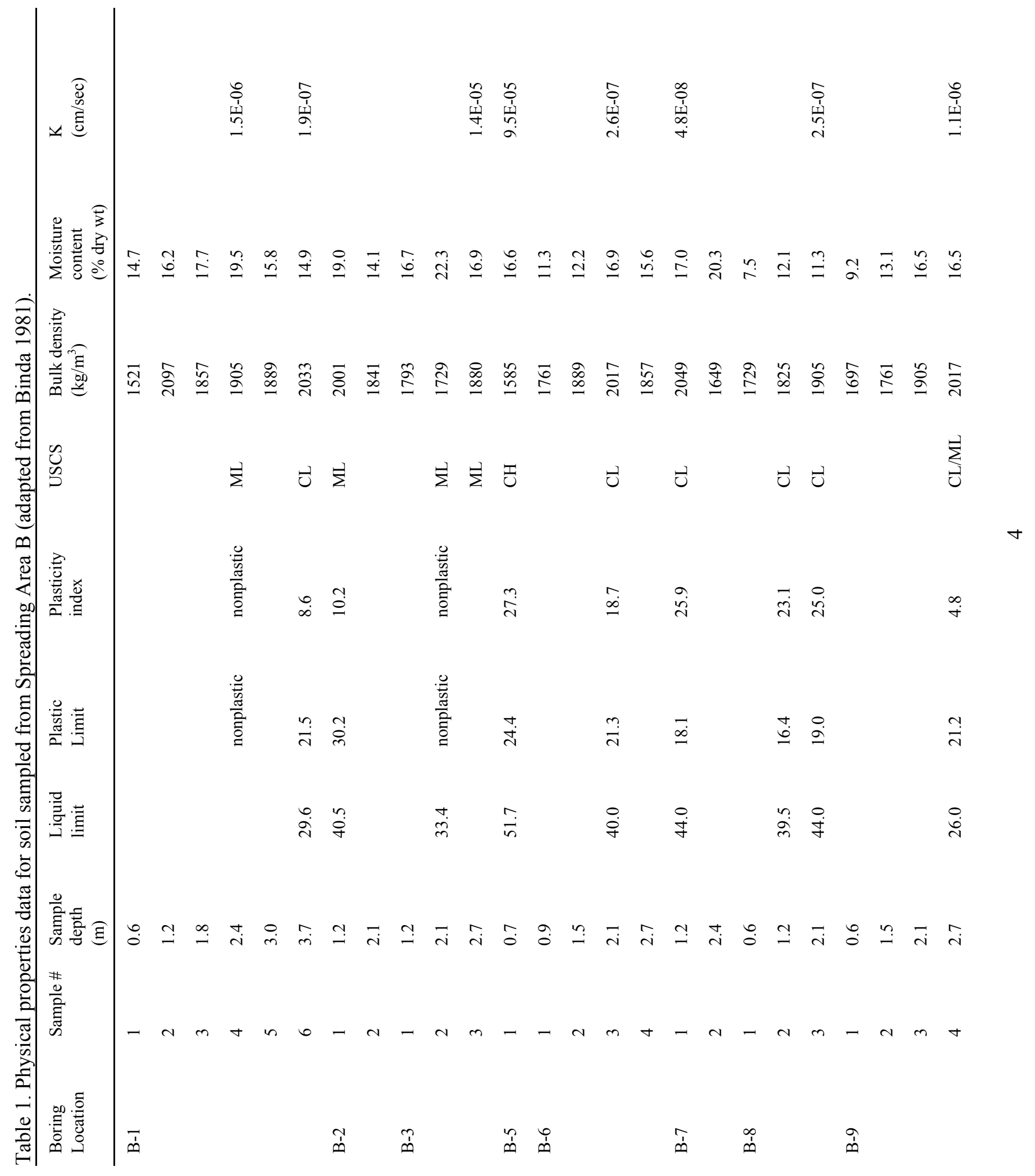




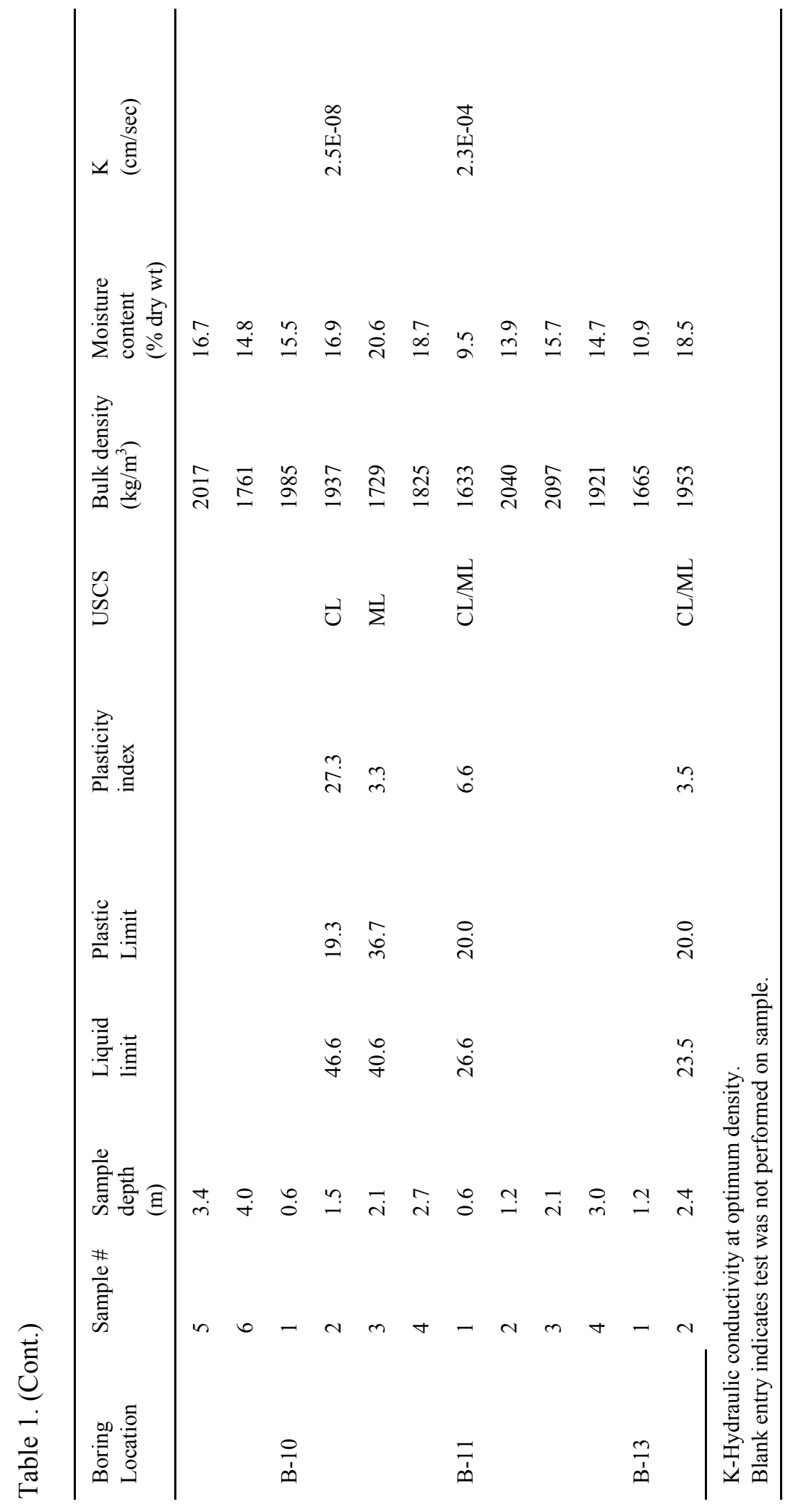




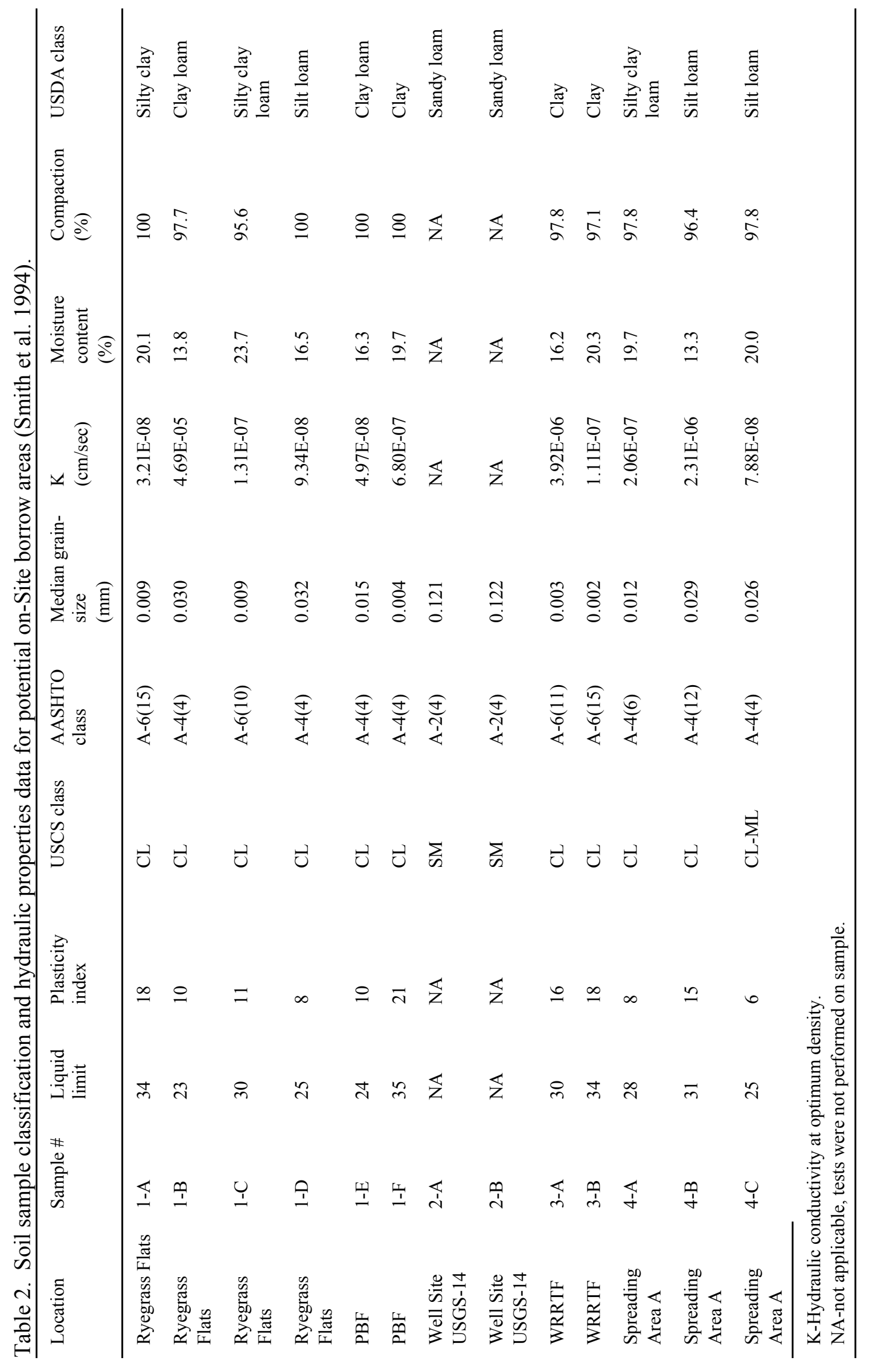


from maintenance of interim covers currently in place. An Engineered Barriers Test Facility (EBTF) was constructed in 1996 to test the effectiveness of different soil closure cover concepts (Porro and Keck 1997, 1998). Tests were conducted to evaluate the capacity of two storage-evapotranspiration type soil covers to recover from extreme wetting under less than ideal conditions. Significant differences were observed in the hydrologic behavior between monolithic and capillary barrier covers (Porro 2001). Unlike the monolithic cover, the capillary barrier cover was able to recover from extreme wetting and stop drainage from annual infiltration events under bare surface conditions (without the aid of plant transpiration) within two years of extreme wetting. The results will be used to support future decisions regarding disposal facility closure options.

The final closure cover design for the active LLW disposal area is now being assessed in the CERCLA RI/FS for Operable Unit 7-13/14 (Seitz et al. 2001). Requirements of DOE Order 435.1 and constraints derived from the results of the PA (Case et al. 2000) are being identified to ensure that they are considered as part of the CERCLA decision process. Closure of the active LLW disposal area under CERCLA will likely include the use of a cover to limit infiltration to an average of at most $1 \mathrm{~cm} / \mathrm{yr}$, the infiltration rate assumed in the RWMC PA (Case et al. 2000 and Seitz et al. 2001). This is also roughly equivalent to the natural background infiltration rate observed around the RWMC. The final cover will also be sufficient to meet the requirements of the intrusion scenarios including assumptions regarding

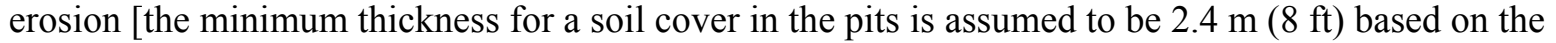
current PA] (Seitz et al. 2001).

\subsection{Waste Disposal Characteristics}

Current operations within the active LLW disposal area consist of subsurface burial of LLW in pits and concrete vaults (see Figures 2 and 3). Trench burial was discontinued in 1982. Pits 17 through 20 in the SDA, concrete vaults within Pit 20, and Soil Vault Rows (SVRs) 14 through 20 have been used for waste disposal since 1984 (see Figures 1and 2 and drawing of SDA in Appendix A). Use of the SVRs was discontinued in 1993. Waste placed in the active LLW disposal area is classified as remote-handled or contact-handled LLW depending on whether radiation levels at $1 \mathrm{~m}(3.3 \mathrm{ft})$ from the package surface are greater than or less than $500 \mathrm{mR} / \mathrm{hr}$, respectively. In general, containerized remote-handled LLW has been entombed in either soil vaults or concrete vaults and contact-handled LLW is stacked in the open areas of the pits. Occasionally, large bulky items classified as remote-handled waste that are unsuitable for vault disposal are placed in an isolated area of Pits 17 and 18, termed the "bulk pit" (see Figure 2), even though the $500-\mathrm{mR} / \mathrm{hr}$ exposure rate is exceeded.

Bulk, containerized contact-handled LLW is currently disposed in Pits 17 through 20. The pits

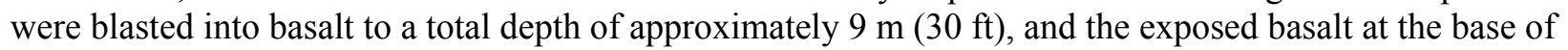
the pits was covered with $0.6 \mathrm{~m}(2 \mathrm{ft})$ of soil. Pits 17 through 20 cover an area of roughly 3.14 ha (7.76 acres). A contoured earthen berm surrounds the pits to control intermittent storm water and snowmelt. Contact-handled wastes were often conditioned prior to being packaged. Conditioning methods included compaction or thermal treatment (incineration), sizing of large metal or wooden items to fit in standard containers, and stabilization of liquid wastes. However, much of this conditioning was discontinued in April 2002. Contact-handled wastes are placed directly in metal or wooden boxes, reinforced soft-sided containers, and other specialized containers, which meet the waste acceptance criteria, and are stacked within the pits using forklifts and cranes. The stack height is limited by the self-supporting strength of the

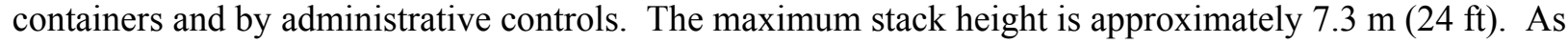

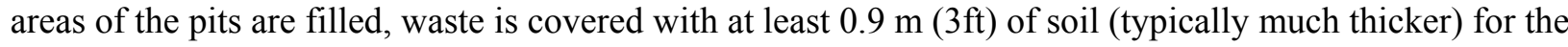
interim cover (see Figure 2). 


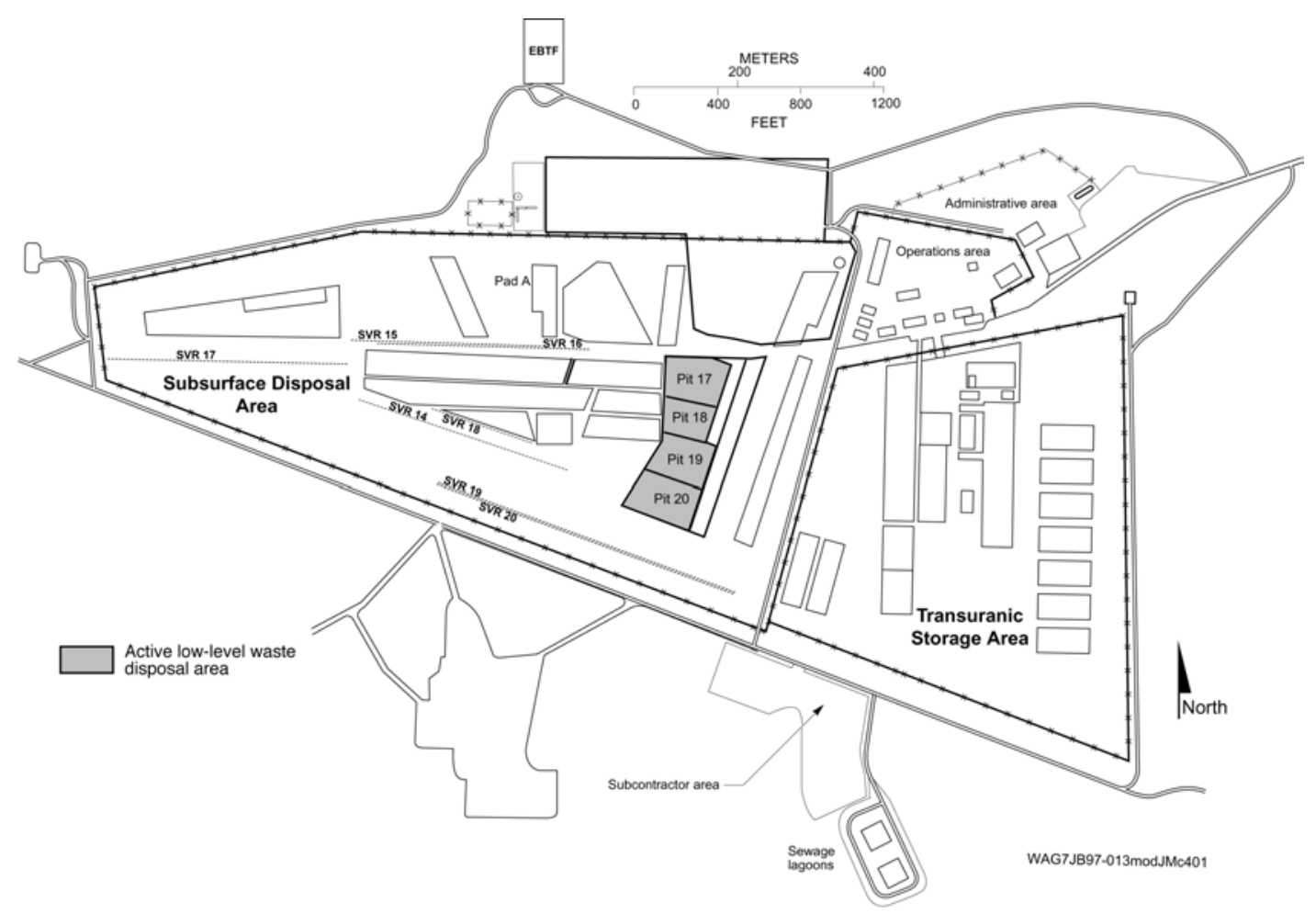

Figure 2. Facilities at the RWMC, including the active LLW disposal pits and soil vault rows.

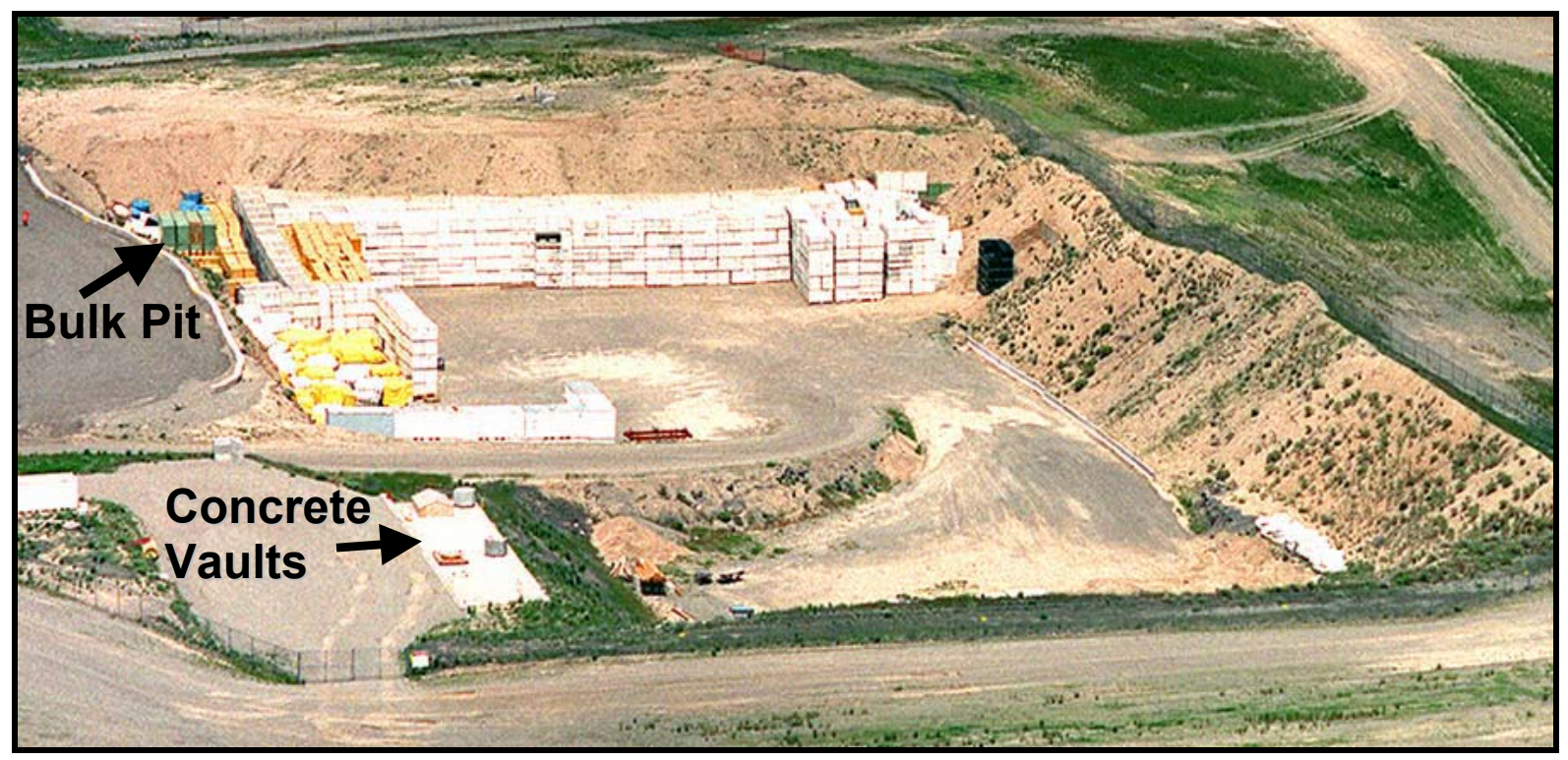

Figure 3. Photo of currently operating LLW disposal pits within the SDA. 
Remote-handled wastes were historically disposed of in the soil vaults and are currently being disposed of in concrete vaults or in the "bulk pit". Most remote-handled wastes disposed in the concrete vaults are packaged in specialized containers. In some cases, specially designed, drainable metal wastebaskets, which are transferred into the vaults from a bottom-discharging shipping cask, are used. The concrete vaults are located in the southwest corner of Pit 20 (see Figure 3). The concrete vaults were designed to conserve space within the active LLW disposal area and provide a rigid structure. Constructed of pre-cast reinforced concrete manhole sections resting on an integral base plate capped with a concrete plug, the vaults are configured in honeycomb arrays. The vaults are surrounded by soil for additional shielding and seismic stability, and the void spaces between the vaults in each array are filled with sand. Dimensions and the layout of the original set of 100 vaults are provided in drawings found in Appendix B. Thirteen of the vaults include high-density polyethylene liners, which are not taken credit for in any assessments. One additional set of 100 vaults will be constructed prior to closure of the facility for a total of 200 vaults. The total number of vaults has recently been reduced from 400 to 200 due to plans to discontinue disposal operations by 2009.

Soil vaults were used for disposal of remote-handled LLW prior to construction of the concrete vaults. The soil vaults comprised unlined holes bored directly in the native soil 5.2 to $7.6 \mathrm{~m}$ (17 to $25 \mathrm{ft}$ ) deep. SVRs 14 through 20 are outside the active LLW disposal area but within the SDA and cover an area of roughly $650 \mathrm{~m}^{2}\left(7000 \mathrm{ft}^{2}\right)$ (see Figure 2$)$. After a vault was filled, it was covered with several feet of soil. The interim cover is already in place over the SVRs as they are no longer used for disposal.

\subsection{Wastes and Waste Forms}

LLW generated at the INEEL primarily consists of contaminated or potentially-contaminated protective clothing, paper, rags, packing material, glassware, tubing, debris and other general use items (Keck and Bhatt 1996). Additional wastes include contaminated equipment and process waste (such as filter cartridges, ion-exchange resins, and sludges). These materials are either surface contaminated with radionuclides or are activated from nuclear reactions. LLW disposed in the SDA must meet the requirements of the INEEL Reusable Property, Recyclable Materials, and Waste Acceptance Criteria (RRWAC). Prior to May 2002, wastes were divided into four categories: non-processible (direct disposal) waste, incinerable waste, compactable waste and sizable waste. These categories of waste are described in the following paragraphs. Note that since May 2002, the only wastes being processed for volume reduction are liquids. Thus, nearly all LLW are being directly disposed.

Nonprocessible waste includes items that could not be processed at the INEEL Waste Reductions Operations Complex (WROC) due to radiation levels, size, or composition. These wastes were and continue to be directly disposed at the SDA. The wastes are disposed in wooden boxes, soft-sided containers, metal bins, cargo containers, steel drums, and specialized containers made of stainless steel.

Incinerable waste comprised rags, plastics, wood, and other combustible material with a radiation level less than $20 \mathrm{mR} / \mathrm{hr}$ at contact. Most incinerable waste was packaged in cardboard boxes and shipped to WROC where it was incinerated. A volume reduction ratio of 50:1 to 300:1 was obtained depending on the type of material incinerated. The ash was solidified in cement in 71-gal drums to stabilize chemically hazardous levels of lead and cadmium in order to render the final waste form as non-hazardous waste. When the stabilized fly ash passed the toxicity characterization leaching procedure testing, disposal at the SDA was permitted.

Compactible waste comprised LLW that could not be incinerated at WROC, but could be compacted. Waste suitable for compaction generally contained halogens, sulfur or rubber materials with radiation levels less than $200 \mathrm{mR} / \mathrm{hr}$ at contact. Compaction achieved a volume reduction of about 5:1. After compaction the waste was disposed at the SDA in metal boxes. Sizable waste comprised metals with 
wall-thickness too great for compaction, radiation levels less than $100 \mathrm{mR} / \mathrm{hr}$ at contact, and free of toxic and hazardous material. Sizing generally resulted in about 4:1 volume reduction. The sized waste was packaged and shipped to the RWMC for disposal.

Given that incineration, compaction and sizing are no longer conducted at the INEEL, it is important to understand the typical void volume found in containers of LLW. In an earlier study, Garcia et al. (1995) opened boxes of LLW packaged at INEEL facilities over a three-year period. Individual items were inventoried, documented, measured and weighed. The actual non-compactible volume was estimated as $37 \%$, with a standard deviation of $\pm 17 \%$. The average void volume in boxes was determined to be $30 \% \pm 13 \%$. Waste that was volume reduced using WROC treatment technologies including compaction, incineration and metal sizing, comprised an average of $34 \% \pm 14 \%$ void volume reduction in boxes. The authors determined that the volume reduction theoretically achievable was approximately $50 \%$. It is therefore likely that containers, equipment, etc. with significant void content, or with high potential for degradation and collapse, are distributed throughout the SDA. Subsidence that occurs before final closure can be repaired while subsidence that occurs after final closure can damage the final closure cover. The nature of metal containers presents a longer-term subsidence risk at the SDA, because they take longer to collapse and may not fail before closure. Estimates of drum failure rates for steel drums of waste buried in shallow pits and trenches at the SDA indicate an average and maximum failure rate of 12 and 24 years, respectively (Martian and Sondrup 1995). Section 2 includes detailed descriptions of subsidence that has been observed at the SDA and discusses the potential for future subsidence in more detail. 


\section{LANDFILL SUBSIDENCE}

Landfill subsidence is the differential settling of waste and or soil from an initial elevation to a lower elevation. Landfill subsidence results from primary consolidation and secondary compression of the waste mass, and from collapse of voids or cavities in the fill and around containers by corrosion, oxidation, or biochemical decay of waste materials.

Total subsidence in the cover will be a cumulative of settlement amounts due to deformation in the following landfill components:

- Consolidation of the waste that is soil,

- Consolidation of the waste due to degradation of waste debris,

- Consolidation due to voids left in containerized waste,

- Consolidation of the foundation soils,

- Consolidation of the cover itself.

Settlement occurring after closure causes surface subsidence and possible cover damage. Although the landfill can and should be constructed so that most of the settlement will occur before closure, it is inevitable that some will occur later. Subsidence of the final landfill cover can result in (EPA, 1987):

- Differential settlement of fill and final cover resulting in development of tension cracks in soils, and tensile or shear failures in geomembranes.

- Settlement of fill and final cover resulting in reduced drainage of water from the cover and ponding of water on the final cover and/or accelerated erosion of the cover.

- Collapse or piping of final cover soils into underlying cavities in the fill, resulting in sinkhole-type depressions in the final cover.

Overall, subsidence reduces the effectiveness of the cover in meeting performance objectives. The most significant adverse effect of cover damage due to subsidence is increased potential for exposures. Erosion due to subsidence can reduce soil shielding thickness and/or expose waste, resulting in increased direct exposures. Sinkhole-type depressions in the cover can result in ponding of water and development of preferential flowpaths, potentially resulting in increased contaminant migration to groundwater and increased exposures.

\subsection{Observed Subsidence at SDA}

Nineteen years of SDA monthly inspection records from 1983 to 2002, maintained by the INEEL Environmental Monitoring Department, were reviewed. Over 160 subsidences were recorded during this period, both in field logs and in photos. In most cases, the inspector reported the length, width, maximum depth and average depth, and the date of the observation. The results including the arithmetic mean and sample standard deviation are summarized in Table 3 for the years 1983 to 1997 . The records for this period are not complete, for example sixteen areas of subsidence were reported in April of 1989, but the 
attachment recording the specific locations and dimensions was apparently lost. Based on anecdotal accounts, RWMC operations may have reportedly filled subsidences observed between inspections without recording the event. The summary statistics for time to occurrence of the subsidence after closure of the disposal unit are skewed, since no records of subsidences before 1983 are available. Thirty years lapsed between the first trench closure and the beginning of the 1983 records, and any subsidence that occurred during this period are not recorded in the current records. Therefore, the mean and standard deviation of time to occurrence are almost certainly skewed toward longer times. Selected photos of SDA subsidence features, provided by the INEEL Environmental Monitoring Department, are included in Appendix C. Pit 17 of the active LLW disposal area had a subsidence event in 1986 that was $9 \mathrm{~m}(30 \mathrm{ft})$ long and $9 \mathrm{~m}(30 \mathrm{ft})$ wide with an average depth of $0.3 \mathrm{~m}(1 \mathrm{ft})$ and a maximum depth of $0.5 \mathrm{~m}(1.5 \mathrm{ft})$. Another subsidence was observed in Pit 17 in May of 1987 that was $3.7 \mathrm{~m}(12 \mathrm{ft})$ long and $3.7 \mathrm{~m}(12 \mathrm{ft})$ wide with an average depth of $0.9 \mathrm{~m}(3 \mathrm{ft})$ and a maximum depth of $1 \mathrm{~m}(3.5 \mathrm{ft})$. In April of 1989 several subsidences were observed in SVRs 15 and 17. Two subsidences were observed in SVR 15 that were 2.7

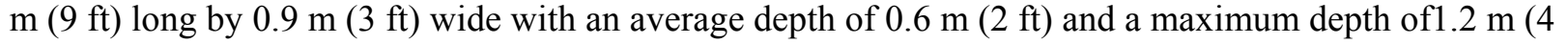

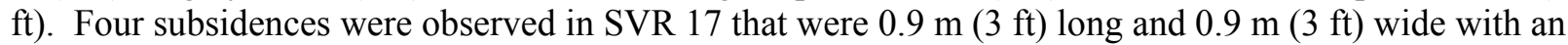
average depth of $0.38 \mathrm{~m}(1.25 \mathrm{ft})$ and a maximum of $0.6 \mathrm{~m}(2 \mathrm{ft})$.

Table 4 provides subsidence occurrences observed from more recent years 1996 to 2002 after major recontouring efforts were performed on the SDA interim cover. The number of occurrences ranges from five in 2001 to 17 in 1998. Some areas of subsidence have been long and narrow [ $101 \times 1 \mathrm{~m}$ $(330 \times 4 \mathrm{ft})]$ and some are almost square $[12 \times 11 \mathrm{~m}(39 \times 35 \mathrm{ft})]$. Depths ranged from $8 \mathrm{~cm}(3 \mathrm{in}$.) to $4 \mathrm{~m}$ (12 ft). Pad A is the only location in the SDA where subsidence is persistent. No subsidences were observed in the active LLW disposal area (Pits 17-20) during this period.

In spite of the data gaps in the records, several trends are evident. First, the highest occurrence of subsidence observations is typically in March or April of each year. This is likely due to: 1) the fact that the March or April inspection is frequently the first of the year, since inspectors are not always able to

Table 3. Summary statistics for Subsurface Disposal Area subsidence features observed from 1983 to 1997.

\begin{tabular}{lllll}
\hline Measurement & Minimum & Maximum & $\begin{array}{l}\text { Sample standard } \\
\text { deviation }\end{array}$ & Arithmetic mean \\
\hline Length (ft) & 1.5 & 192 & 33.75 & 24.41 \\
Width (ft) & 0.75 & 66 & 8.94 & 8.78 \\
$\begin{array}{l}\text { Maximum depth of } \\
\text { subsidence (ft) }\end{array}$ & NA & 8 & 1.55 & 1.99 \\
$\begin{array}{l}\text { Average depth of } \\
\text { subsidence (ft) }\end{array}$ & NA & NA & 1.13 & 1.37 \\
$\begin{array}{l}\text { Time to } \\
\text { occurrence after } \\
\text { disposal unit } \\
\text { closure (days) }\end{array}$ & 163 & 12675 & 2733 & 6261 \\
\hline
\end{tabular}


Table 4. Subsidence data collected from 1996 to 2002 for the Subsurface Disposal Area.

\begin{tabular}{|c|c|c|c|c|c|}
\hline Location & Length & Width & $\begin{array}{l}\text { Average } \\
\text { Depth }\end{array}$ & $\begin{array}{l}\text { Maximum } \\
\text { Depth }\end{array}$ & $\begin{array}{c}\text { Exposed } \\
\text { Waste }\end{array}$ \\
\hline \multicolumn{6}{|l|}{ April 2002} \\
\hline $\mathrm{T}-50$ & $40 \mathrm{ft}$ & $21 \mathrm{ft} 6$ in. & 8 in. & 40 in. & No \\
\hline $\mathrm{T}-52$ & $21 \mathrm{ft}$ & $7 \mathrm{ft}$ & $12 \mathrm{in.}$ & 16 in. & No \\
\hline Pit 6 & $21 \mathrm{ft}$ & $20 \mathrm{ft}$ & 8 in. & 8 in. & No \\
\hline SVR-16 & $4 \mathrm{ft} 7 \mathrm{in}$. & $4 \mathrm{ft} 4$ in. & $20 \mathrm{in.}$ & $25 \mathrm{in.}$ & No \\
\hline Pit 2 & $10 \mathrm{ft}$ & $6 \mathrm{ft} 6$ in. & 24 in. & $4 \mathrm{ft}$ & No \\
\hline Pit 4 & $15 \mathrm{ft}$ & $7 \mathrm{ft}$ & 14 in. & $4 \mathrm{ft} 6$ in. & No \\
\hline Pad A & $11 \mathrm{ft}$ & $3 \mathrm{ft} 6$ in. & 8 in. & $4 \mathrm{ft}$ & No \\
\hline \multicolumn{6}{|l|}{ April 2001} \\
\hline Mixed Waste (MW) Trench 1 & 40 in. & $12 \mathrm{in.}$ & $24 \mathrm{in.}$ & $8 \mathrm{ft} 6$ in. & No \\
\hline $\begin{array}{l}\text { Low-Level Waste (LLW) } \\
\text { Trench } 58\end{array}$ & $8 \mathrm{ft}$ & $4 \mathrm{ft}$ & $4 \mathrm{in.}$ & $12 \mathrm{in.}$ & No \\
\hline Pad A (northeast) & $23 \mathrm{ft}$ & $3 \mathrm{ft} 6$ in. & 4 in. & 36 in. & No \\
\hline Pit 4 & $7 \mathrm{ft} 6$ in. & $5 \mathrm{ft}$ & 3 in. & $24 \mathrm{in.}$ & No \\
\hline MW Trench 5 & 18 in. & 8 in. & 18 in. & 24 in. & No \\
\hline \multicolumn{6}{|l|}{ October 2000} \\
\hline LLW Pit 15 fence line & $115 \mathrm{ft}$ & $1 / 4$ to $1 / 8 \mathrm{in}$. & $1 \mathrm{in.}$ & $40 \mathrm{in.}$ & No \\
\hline LLW Pit 15 fence line & $15 \mathrm{in.}$ & 12 in. & $10 \mathrm{in.}$ & $40 \mathrm{in.}$ & No \\
\hline MW Trench 47 & $26 \mathrm{in.}$ & $24 \mathrm{in.}$ & 18 in. & $9 \mathrm{ft}$ & No \\
\hline \multicolumn{6}{|l|}{ March 2000} \\
\hline LLW Pad A (cracks) & $12 \mathrm{ft}$ & $1 / 2$ to $2 \mathrm{in}$. & 1 to 2 in. & $3 \mathrm{in.}$ & No \\
\hline LLW Pad A (cracks) & $16 \mathrm{ft}$ & $1 / 2$ to 2 in. & 1 to 2 in. & 3 in. & No \\
\hline \multicolumn{6}{|l|}{ August 1999} \\
\hline MW Pit 4 & $16 \mathrm{ft}$ & $8 \mathrm{ft}$ & $12 \mathrm{in.}$ & $2 \mathrm{ft} 6$ in. & No \\
\hline \multicolumn{6}{|l|}{ June 1999} \\
\hline MW Trench 49 & $8 \mathrm{ft}$ & 40 in. & 15 in. & $5 \mathrm{ft}$. & No \\
\hline \multicolumn{6}{|l|}{ April 1999} \\
\hline MW Trench 51 & $179 \mathrm{ft}$ & $17 \mathrm{ft}$ & 17 in. & $3 \mathrm{ft}$ & No \\
\hline LLW Pit 15 & $25 \mathrm{ft}$ & $7 \mathrm{ft}$ & $3 \mathrm{ft}$ & $12 \mathrm{ft}$ & Yes \\
\hline LLW Pit 16 fence line & $300 \mathrm{ft}$ & $4 \mathrm{ft}$ & 6 in. & $2 \mathrm{ft}$ & No \\
\hline MW Trench 41 & $18 \mathrm{ft}$ & $20 \mathrm{ft}$ & $12 \mathrm{in.}$ & $18 \mathrm{in.}$ & No \\
\hline MW Pit 12 & $18 \mathrm{ft}$ & $7 \mathrm{ft}$ & $12 \mathrm{in.}$ & $20 \mathrm{in.}$ & No \\
\hline MW Trench 47 & $58 \mathrm{ft}$ & $8 \mathrm{ft}$ & $20 \mathrm{in.}$ & $4 \mathrm{ft}$ & No \\
\hline MW Trench 36 & $8 \mathrm{ft}$ & $10 \mathrm{ft}$ & $6 \mathrm{in.}$ & $8 \mathrm{ft}$ & No \\
\hline MW Trench 36 & $39 \mathrm{ft}$ & $35 \mathrm{ft}$ & 6 in. & $2 \mathrm{ft}$ & No \\
\hline
\end{tabular}




\begin{tabular}{|c|c|c|c|c|c|}
\hline Location & Length & Width & $\begin{array}{l}\text { Average } \\
\text { Depth }\end{array}$ & $\begin{array}{l}\text { Maximum } \\
\text { Depth }\end{array}$ & $\begin{array}{l}\text { Exposed } \\
\text { Waste }\end{array}$ \\
\hline MW Trench 16 & $36 \mathrm{ft}$ & $10 \mathrm{ft}$ & $6 \mathrm{in.}$ & $30 \mathrm{in.}$ & No \\
\hline MW Pit 10 & $35 \mathrm{ft}$ & $30 \mathrm{ft}$ & $6 \mathrm{in.}$ & $10 \mathrm{in.}$ & No \\
\hline MW Pit 10 & $30 \mathrm{ft}$ & $37 \mathrm{ft}$ & $6 \mathrm{in.}$ & $10 \mathrm{in.}$ & No \\
\hline MW Trench 38 & $12 \mathrm{ft}$ & $6 \mathrm{ft}$ & $12 \mathrm{in.}$ & $2 \mathrm{ft}$ & No \\
\hline MW Trench 7 & $26 \mathrm{ft}$ & $9 \mathrm{ft}$ & $6 \mathrm{in.}$ & $8 \mathrm{in.}$ & No \\
\hline MW Trench 7 & $4 \mathrm{ft}$ & $5 \mathrm{ft}$ & 4 in. & $12 \mathrm{in.}$ & No \\
\hline $\begin{array}{l}\text { Soil Vault Row (SVR) } 18 \\
\text { (by Pit 13) }\end{array}$ & $18 \mathrm{in.}$ & 16 in. & 14 in. & 16 in. & No \\
\hline \multicolumn{6}{|l|}{ June 1998} \\
\hline MW Trench 7 & $26 \mathrm{in.}$ & $12 \mathrm{in.}$ & $11 \mathrm{in.}$ & $14 \mathrm{in.}$ & No \\
\hline LLW Trench 58 & $24 \mathrm{in.}$ & $9 \mathrm{in.}$ & 8 in. & $60 \mathrm{in.}$ & No \\
\hline MW Trench 6 & 36 in. & 36 in. & $9 \mathrm{in.}$ & 9 in. & No \\
\hline MW Trench 6 & 112 in. & $7 \mathrm{ft}$ & $20 \mathrm{in.}$ & $24 \mathrm{in.}$ & No \\
\hline MW Trench 6 & $12 \mathrm{ft}$ & $6 \mathrm{ft}$ & $25 \mathrm{in.}$ & $30 \mathrm{in.}$ & No \\
\hline MW Trench 6 & $3 \mathrm{ft}$ & $12 \mathrm{in.}$ & $18 \mathrm{in.}$ & $20 \mathrm{in.}$ & No \\
\hline MW Trench 47 or 49 & $32 \mathrm{in.}$ & $32 \mathrm{in.}$ & $10 \mathrm{in.}$ & $19 \mathrm{in.}$ & No \\
\hline LLW Pit 16 & $18 \mathrm{ft}$ & 36 in. & $18 \mathrm{in.}$ & 18 in. & No \\
\hline MW Trench 58 & $8 \mathrm{ft}$ & $4 \mathrm{ft}$ & $12 \mathrm{in.}$ & $4 \mathrm{ft} 6$ in. & No \\
\hline MW Trench 14 & $7 \mathrm{ft}$ & $6 \mathrm{ft} 6$ in. & $12 \mathrm{in.}$ & $5 \mathrm{ft} 6$ in. & No \\
\hline MW SVR 14 & $15 \mathrm{in.}$ & $15 \mathrm{in.}$ & $16 \mathrm{in.}$ & $16 \mathrm{in.}$ & No \\
\hline MW SVR 14 & $3 \mathrm{ft}$ & $2 \mathrm{ft} 6$ in. & $12 \mathrm{in.}$ & $16 \mathrm{in.}$ & No \\
\hline MW SVR 14 & $4 \mathrm{ft} 6$ in. & $40 \mathrm{in.}$ & $32 \mathrm{in.}$ & $32 \mathrm{in.}$ & No \\
\hline MW Trench 45 & $40 \mathrm{ft}$ & $6 \mathrm{ft}$ & 8 in. & $24 \mathrm{in.}$ & No \\
\hline LLW Pad A & 8 in. & $14 \mathrm{ft}$. & Filled & Filled & No \\
\hline LLW Pad A & $24 \mathrm{in.}$ & $24 \mathrm{in.}$ & 9 in. & $24 \mathrm{in.}$ & No \\
\hline LLW Trench 57 & $21 \mathrm{in.}$ & $21 \mathrm{in.}$ & $5 \mathrm{in.}$ & 8 in. & No \\
\hline MW SVR 17 & $5 \mathrm{ft}$ & $6 \mathrm{ft} 4 \mathrm{in}$. & 8 in. & $14 \mathrm{in.}$ & No \\
\hline MW SVR 17 & $5 \mathrm{ft}$ & $5 \mathrm{ft}$ & $6 \mathrm{in.}$ & $6 \mathrm{in.}$ & No \\
\hline MW SVR 17 & $5 \mathrm{ft} 2$ in. & $5 \mathrm{ft} 5$ in. & 5 in. & $5 \mathrm{in.}$ & No \\
\hline MW SVR 17 & $5 \mathrm{ft} 4$ in. & $5 \mathrm{ft} 5$ in. & 4 in. & $4 \mathrm{in.}$ & No \\
\hline MW SVR 17 & 5 ft. 5 in. & $5 \mathrm{ft} 10$ in. & 8 in. & 17 in. & No \\
\hline MW SVR 17 & $5 \mathrm{ft} 3$ in. & $5 \mathrm{ft} 10 \mathrm{in}$. & 8 in. & 8 in. & No \\
\hline MW SVR 17 & $5 \mathrm{ft}$ & $5 \mathrm{ft}$ & $9 \mathrm{in.}$ & $9 \mathrm{in.}$ & No \\
\hline MW SVR 17 & $4 \mathrm{ft} 4 \mathrm{in}$. & $5 \mathrm{ft}$ & $6 \mathrm{in.}$ & $6 \mathrm{in.}$ & No \\
\hline MW SVR 17 & $5 \mathrm{ft}$ & $7 \mathrm{ft}$ & $12 \mathrm{in.}$ & $12 \mathrm{in.}$ & No \\
\hline MW SVR 17 & $5 \mathrm{ft} 3$ in. & $5 \mathrm{ft} 10$ in. & $24 \mathrm{in.}$ & $24 \mathrm{in.}$ & No \\
\hline MW SVR 17 & $6 \mathrm{ft}$ & $7 \mathrm{ft}$ & 5 in. & 15 in. & No \\
\hline
\end{tabular}




\begin{tabular}{|c|c|c|c|c|c|}
\hline Location & Length & Width & $\begin{array}{l}\text { Average } \\
\text { Depth }\end{array}$ & $\begin{array}{l}\text { Maximum } \\
\text { Depth }\end{array}$ & $\begin{array}{c}\text { Exposed } \\
\text { Waste }\end{array}$ \\
\hline MW Trench 45 & $4 \mathrm{ft} 7$ in. & $9 \mathrm{ft} 9$ in. & 8 in. & 8 in. & No \\
\hline Gate 26 & $7 \mathrm{ft}$ & $9 \mathrm{ft}$ & $12 \mathrm{in.}$ & $12 \mathrm{in.}$ & No \\
\hline Pad A & $42 \mathrm{ft}$ & 19 to $29 \mathrm{ft}$ & $10 \mathrm{ft}$ & $10 \mathrm{ft}$ & Yes \\
\hline \multicolumn{6}{|l|}{ October 1996} \\
\hline SVR 17 & 36 in. & 33 in. & $10 \mathrm{in.}$ & $1 \mathrm{ft}$ & No \\
\hline Pad A & $1 \mathrm{ft} 17$ in. & $17 \mathrm{in.}$ & $2 \mathrm{ft} 6$ in. & $3 \mathrm{ft}$ & No \\
\hline Pad A & $1 \mathrm{ft} 6$ in. & $1 \mathrm{ft}$ & $2 \mathrm{ft} 6$ in. & $3 \mathrm{ft}$ & No \\
\hline \multicolumn{6}{|l|}{ February 1996} \\
\hline SVR 17 & $6 \mathrm{ft}$ & $5 \mathrm{ft}$ & $2 \mathrm{ft}$ & 30 in & No \\
\hline Pit 10 & $4 \mathrm{ft}$ & $3 \mathrm{ft}$ & $2 \mathrm{ft}$ & $2 \mathrm{ft}$ & No \\
\hline Pit 10 & $26 \mathrm{in.}$ & 18 in. & 6 in. & $6 \mathrm{in.}$ & No \\
\hline Pit 10 & $23 \mathrm{ft}$ & $15 \mathrm{ft}$ & $18 \mathrm{in.}$ & $3 \mathrm{ft}$ & No \\
\hline Pit 10 & $27 \mathrm{ft}$ & $15 \mathrm{ft}$ & $1 \mathrm{ft}$ & $29 \mathrm{in.}$ & No \\
\hline Pit 10 & $28 \mathrm{ft}$ & $20 \mathrm{ft}$ & 17 in. & 17 in. & No \\
\hline
\end{tabular}

perform walk-overs during the spring thaw, due to muddy conditions, and snow frequently obscures subsidences during winter months; and 2) the effects of thawing combined with rapid infiltration of snowmelt in the development of subsidence.

Second, even with the skewed time to occurrence accounted for, the time to development of subsidence at the SDA is relatively long, compared to that for Resource Conservation and Recovery Act (RCRA) Subtitle C and D landfills. The mean time to development of subsidence of 6261 days (over 17 years) is much longer than the 6 months or a year commonly cited as typical (EPA 1987). This is likely due to the slow deterioration of relatively high-integrity containers.

Third, mean depths of subsidence are less than predicted values for containerized waste landfills. The observed mean subsidence depth value of $0.6 \mathrm{~m}(2 \mathrm{ft})$ is less than the predicted value of $1 \mathrm{~m}(3.4 \mathrm{ft})$, based on the predicted 20\% maximum subsidence (EPA 1987) and a fifteen foot thick waste zone and two feet of soil cover. This can likely be accounted for by the skewed data set, and the trend for the deepest subsidences to occur relatively rapidly. Collapsed soil columns take years to naturally reach their precollapse densities again. Many of the deepest subsidences likely occurred before the period of record.

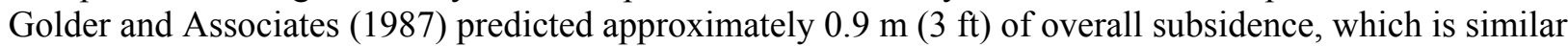
to the observed subsidences.

\subsection{Potential for Subsidence at SDA}

The potential for subsidence at the SDA LLW disposal area is best determined by review of the SDA disposal history in the context of past and current disposal practices, theoretical and empirical predictions, and past observed subsidence. Subsidence does occasionally occur at the SDA because of voids that are present in the waste disposal boxes and containers that are used for waste disposal and because of settling of the cover soils between the containers and less than adequate initial compaction. Procedures are in place for surveillance and maintenance of the existing soil cover including regular filling of any subsidence features (Procedure TPR-EM-EN2.1, RWMC Visual Inspection). Reinforced, 
soft-sided containers, which leave minimal or no voids are being used more often at the SDA (see Figure 3 ). Increased use of these containers is expected to help reduce the potential for subsidence in the future.

EPA (1987) states that differential settlement across short distances is more threatening than relatively uniform settlement across greater distances, with respect to damage to the overlying closure cover. This statement assumes that the cover incorporates compacted clay and/or geosynthetic layers. Even covers that utilize silts and/or a capillary break will suffer from columnar or piston failure caused by localized container failure that is transmitted to the surface. The report further states that the potential for differential settlement is greater at heterogeneous landfills than monofills. Further, settlement in landfills where containers have been utilized is more difficult to predict, and potentially less uniform and therefore more damaging, than in landfills where uncontainerized wastes have been randomly placed. Using the evidence presented in EPA 1987, the potential for subsidence at the SDA, where pits, vaults and trenches have been used to dispose of many varieties of containerized and bulk wastes, would therefore be considered high.

EPA (1987) determined that the expected subsidence of a RCRA landfill cover, resulting only from collapse of voids around containers, would be approximately $12 \%$ of the total distance from the bottom of the waste zone to the crown of the cover. Additional $8 \%$ subsidence may occur if all containers in a landfill contain $10 \%$ void space, resulting in a maximum subsidence of approximately $20 \%$ of the total landfill thickness. Initial subsidence occurs relatively rapidly after closure, but subsequent subsidence resulting from container failures may occur over much longer periods. SDA containers potentially contain much more void space, based on the $15 \%$ void space allowed under the RRWAC, and on the 30$50 \%$ actual void space measured by Garcia et al. (1995) for non-WROC processible containers. The SDA may therefore have a higher theoretical potential for long-term subsidence due to container failure than

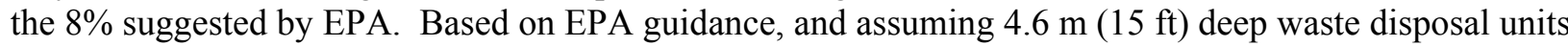
and a $3 \mathrm{~m} \mathrm{(10} \mathrm{ft)} \mathrm{thick} \mathrm{soil} \mathrm{cover,} \mathrm{total} \mathrm{subsidence} \mathrm{due} \mathrm{to} \mathrm{soil} \mathrm{consolidation} \mathrm{and} \mathrm{container} \mathrm{failure} \mathrm{might} \mathrm{be}$ as much as $1.5 \mathrm{~m}(5 \mathrm{ft})$.

Golder and Associates (1987) estimated that a maximum of one inch of settlement might occur per foot of cover material added at the SDA. Long-term settlements might range from two to four inches in areas of bulk waste with no open voids, and up to two ft due to collapse of soil bridges and waste

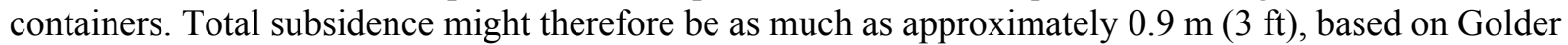
and Associates analysis. Subsidence was expected to be greatest at the edges of waste pits, and in areas with significant quantities of waste containers and large building debris. Golder and Associates suggested that damage to the SDA cover from subsidence could be minimized by using a relatively thick soil closure cover; by not relying on geomembranes to meet performance objectives; and by post-construction monitoring and maintenance.

In summary, it is estimated based on past and current disposal practices, theoretical and empirical predictions, and past observed subsidence at the SDA that there is moderate to high potential for future subsidence at the SDA LLW disposal facility with an average estimate of 0.9 to $1.5 \mathrm{~m}$ ( 3 to $5 \mathrm{ft}$ ). 


\section{SUBSIDENCE CONSIDERATIONS FOR FINAL CLOSURE}

Based on the preceding analysis, there is a high likelihood that subsidence will continue to occur in the SDA after final closure, as currently scheduled to be completed in 2012. Voids that can be present in and around containers, combined with the relatively slow rate of deterioration for many containers, are the primary cause of long-term subsidence. Many differential settlements of sufficient area and depth to damage a final closure cover have been observed. The most severe differential settlement has historically occurred within 10 years of closure of the disposal unit; however, many exceptions to this trend have been reported. Many incidences of subsidence in pits and soil vaults closed after 1984 should occur before final closure in 2012. However, some will continue to occur after that time, based on observations to date at the SDA. Because of the timing of container degradation, disposal units closed after 2002 would likely present the greatest subsidence risks to a final closure cover. These units would include Pits 18-20 in the active LLW disposal area.

Two design criteria have been identified for final closure concepts: a specified infiltration rate (average of $1 \mathrm{~cm} / \mathrm{yr}$ ) and a specified thickness of cover [2.4 $\mathrm{m}(8 \mathrm{ft})$ over the waste in the pits and $3.3 \mathrm{~m}$ (10 ft) over the waste in the soil vaults]. Thus, it is critical that closure concepts considered for the SDA address the potential for subsidence in the course of developing specifications to meet these design criteria. To this end, closure concepts will need to consider the potential for localized differential settlement as described in Section 2.1 as well as the potential for more general subsidence resulting from the loading of cover material above the existing grade. Given that closure of the active LLW disposal pits will be addressed as part of the CERCLA RI/FS and the selected remedial action will be specified in the ROD, any potential remedies to address subsidence will be assessed as part of the CERCLA process. In accordance with this need, options to reduce the potential for subsidence are being considered as part of the on-going RI/FS. 


\section{CONCLUSIONS}

Two key design constraints for a final cover have been specified based on the results of modeling conducted to support the PA and CA that were conducted for the LLW disposal facility at the RWMC. The first constraint addresses the average annual amount of infiltration that can occur through the cover and the second constraint addresses the minimum thickness of the cover. The PA and CA are key documents that contribute to the basis for obtaining a DAS from DOE for continued operation of the disposal facility. The DAS for the LLW disposal facility at the INEEL was granted based on several conditions. Because of concerns about the potential for subsidence and the impacts of subsidence on the performance of the disposal facility, one of the conditions was the need to conduct a subsidence analysis.

Based on past and current disposal practices at the RWMC, theoretical and empirical predictions, and observed subsidence at the SDA, it is concluded that there is a high potential for future subsidence at the SDA LLW disposal facility. This is consistent with the fact that subsidence is known to occur at landfills and other disposal facilities (EPA 1985, 1987). It is estimated that the amount of subsidence would average about 0.9 to $1.5 \mathrm{~m}$ ( 3 to $5 \mathrm{ft}$ ). Based on the types of containers used for waste disposal, it is expected that there will be delays of more than 10 years after disposal before subsidence will typically occur. Thus, subsidence can be expected after closure is completed as planned in 2012. Future subsidence events may reduce the effectiveness of any final closure cover. Therefore, any remedial action and/or final cover design should recognize the potential for subsidence at the SDA and incorporate the appropriate measures to minimize the impact of subsidence. 


\section{REFERENCES}

Binda, R.E., 1981, Evaluation of Final Surface Cover Proposal for the INEL Subsurface Disposal Area, WM-F1-81-007, EG\&G Idaho Inc., Idaho Falls, ID.

Case, M.J., A.S. Rood, J.M. McCarthy, S.O. Magnuson, B.H. Becker, and T.K. Honeycutt, 2000. Technical Revision of the Radioactive Waste Management Complex Low-Level Waste Radiological Performance Assessment for Calendar Year 2000, INEEL/EXT-2000-01089, Idaho National Engineering Laboratory, Lockheed Martin Technologies Co., Idaho Falls, ID, September.

DOE, 1999, Radioactive Waste Management, Office of Environmental Management, DOE O 435.1, United States Department of Energy, Washington DC, July.

EPA, 1987, Prediction/Mitigation of Subsidence Damage to Hazardous Waste Landfill Covers, EPA/600/2-87/025, Hazardous Waste Engineering Research Laboratory, Office of Research and Development, U.S. Environmental Protection Agency, Cincinnati, OH, March.

EPA, 1985, Settlement and Cover Subsidence of Hazardous Waste Landfills, EPA/600/2-85/035, Hazardous Waste Engineering Research Laboratory, Office of Research and Development, U.S. Environmental Protection Agency, Cincinnati, OH, April.

Garcia, J. F., N. R. Soelberg and P. M. Walsh, 1995, Assessment of Untreated Low-Level (LLW) Packaged by INEEL Waste Generators for Direct Disposal at the INEEL LLW Disposal Facility, FY-1995 Progress Report, September.

Golder Associates, Inc., 1987, Master Evaluation of Cover Alternatives and Surface Drainage Design at the SDA, EGG-LLW-8235, November.

Keck, K. N. and R. N. Bhatt, 1996, Preliminary Closure Plan for the SDA Active Low-Level Radioactive Waste Disposal Area, INEL-96/0215, LMITCO, Idaho Falls, ID.

Maheras, S.J., A.S. Rood, S.O. Magnuson, M.E. Sussman, and R.N. Bhatt, 1994, Radioactive Waste Management Complex Low-Level Waste Radiological Performance Assessment, Idaho National Engineering Laboratory, EG\&G Idaho Inc., Idaho Falls, ID, EGG-WM-8773, April.

Maheras, S.J., A.S. Rood, S.O. Magnuson, M.E. Sussman, and R.N. Bhatt, 1997, Addendum to Radioactive Waste Management Complex Low-Level Waste Radiological Performance Assessment, (EGG-WM-8773), Idaho National Engineering Laboratory, Lockheed Martin Idaho Technologies Company, Idaho Falls, ID, INEL/EXT-97-00462, April.

Martian, P. and A.J. Sondrup, 1995, SDA Buried Drum Failure Rate Data Compilation, EDF ER-WAG768, INEL-95/126, EG\&G Idaho Inc., Idaho Falls, ID, May.

McCarthy, J.M., B.H. Becker, S.O. Magnuson, K.N. Keck, and T.K. Honeycutt, 2000, Radioactive Waste Management Complex Low-level Waste Radiological Composite Analysis, Idaho National Engineering and Environmental Laboratory, Bechtel BWXT Idaho, LLC, Idaho Falls, ID, INEEL/EXT-97-01113, September. 
Porro, I., 2001, Hydrologic Behavior of Two Engineered Barriers Following Extreme Wetting, Journal of Environmental Quality, 30:655-667.

Porro, I. and K.N. Keck, 1998, Engineered Barrier Testing at the INEEL Engineered Barriers Test Facility: FY-1997 and FY-1998, INEEL/EXT-98-00964, Lockheed Martin Idaho Technologies Company, Idaho Falls, ID, September.

Porro, I. and K.N. Keck, 1997, Summary of Activities at the Engineered Barriers Test Facility, October 1, 1995 to January 31, 1997, and Initial Data, INEEL/EXT-97-00239, Lockheed Martin Idaho Technologies Company, Idaho Falls, ID, March.

Seitz, R.R., K. N. Keck, and J. M. McCarthy, 2001, Interim Closure Concept for the Low-Level Waste Disposal Facility at the Radioactive Waste Management Complex, INEEL/EXT-00178, Idaho National Engineering and Environmental Laboratory, Idaho Falls, ID, April.

Smith, R. P., H.C. Bean, G. S. Carpenter, and S. C. Minkin, 1994, INEL Alternative Playa Resource Investigation, INEL-94/0234, Lockheed Idaho Technologies Company, Idaho Falls, ID.

Shuman, R., 2000, Maintenance for the Radioactive Waste Management Complex Performance Assessment and Composite Analysis, INEEL/EXT-2000-01262, Idaho National Engineering and Environmental Laboratory, Bechtel BWXT Idaho, LLC, Idaho Falls, ID, September. 


\section{APPENDIX A}

Detailed Drawings of the SDA 


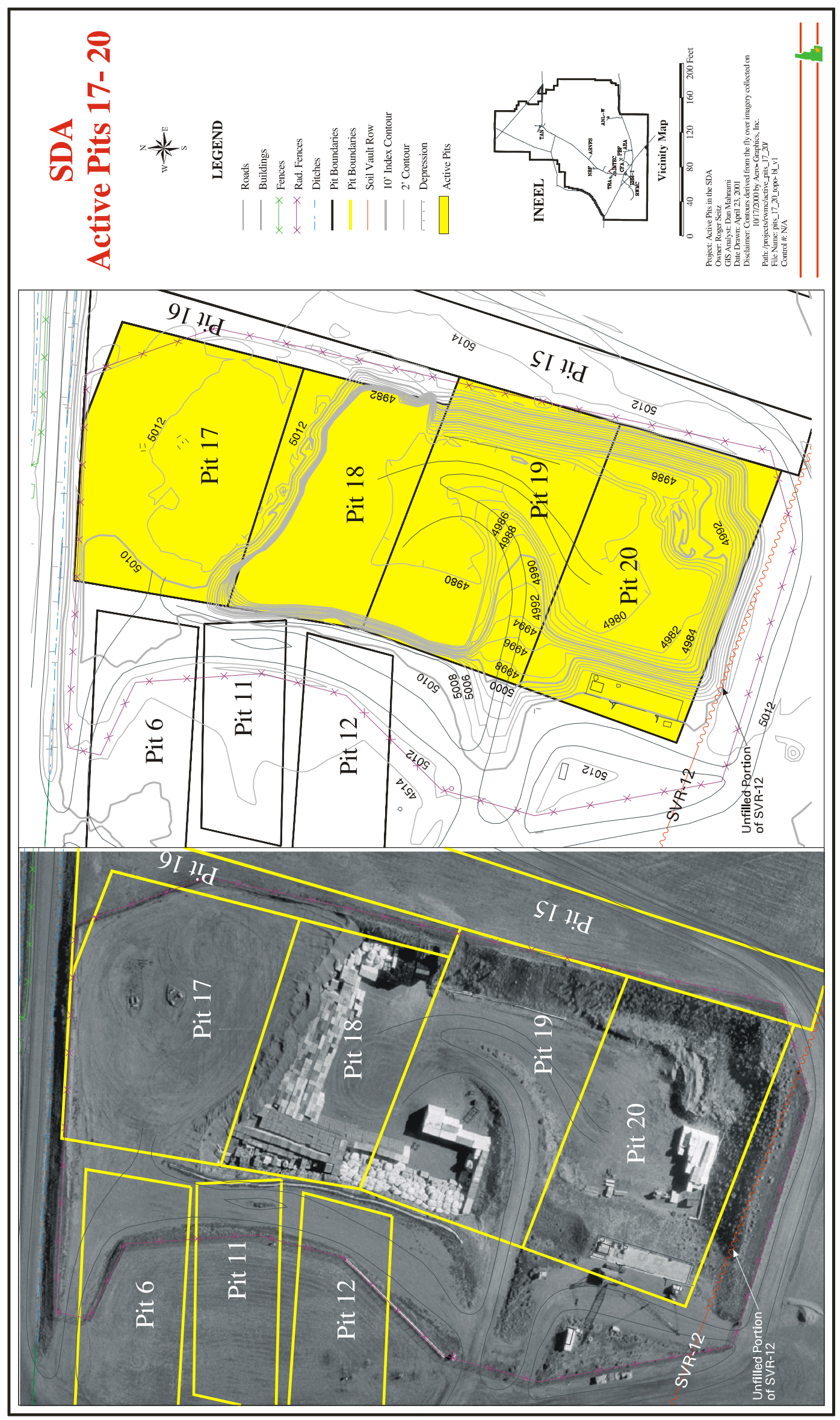




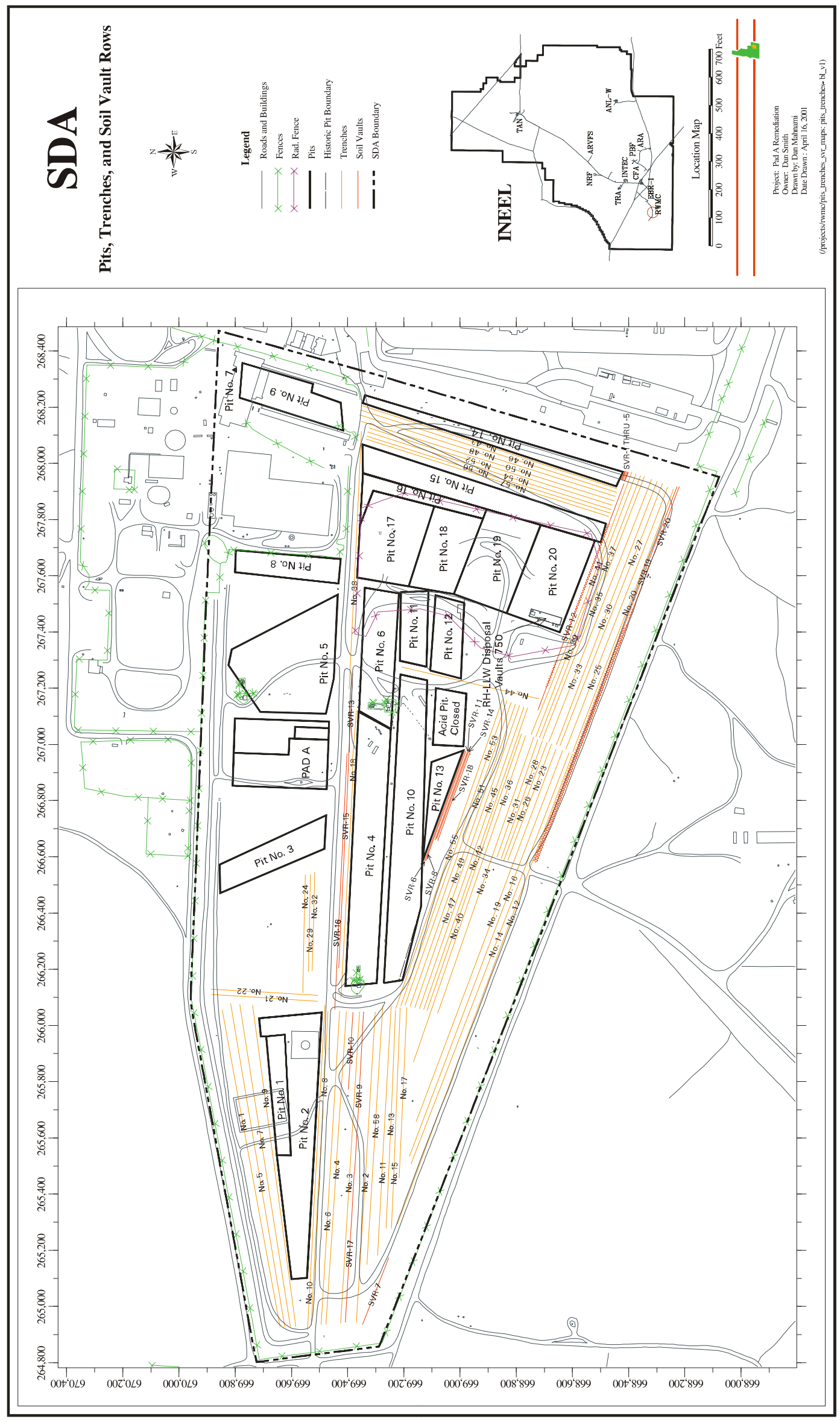




\section{APPENDIX B \\ Drawings of the Concrete Vaults}




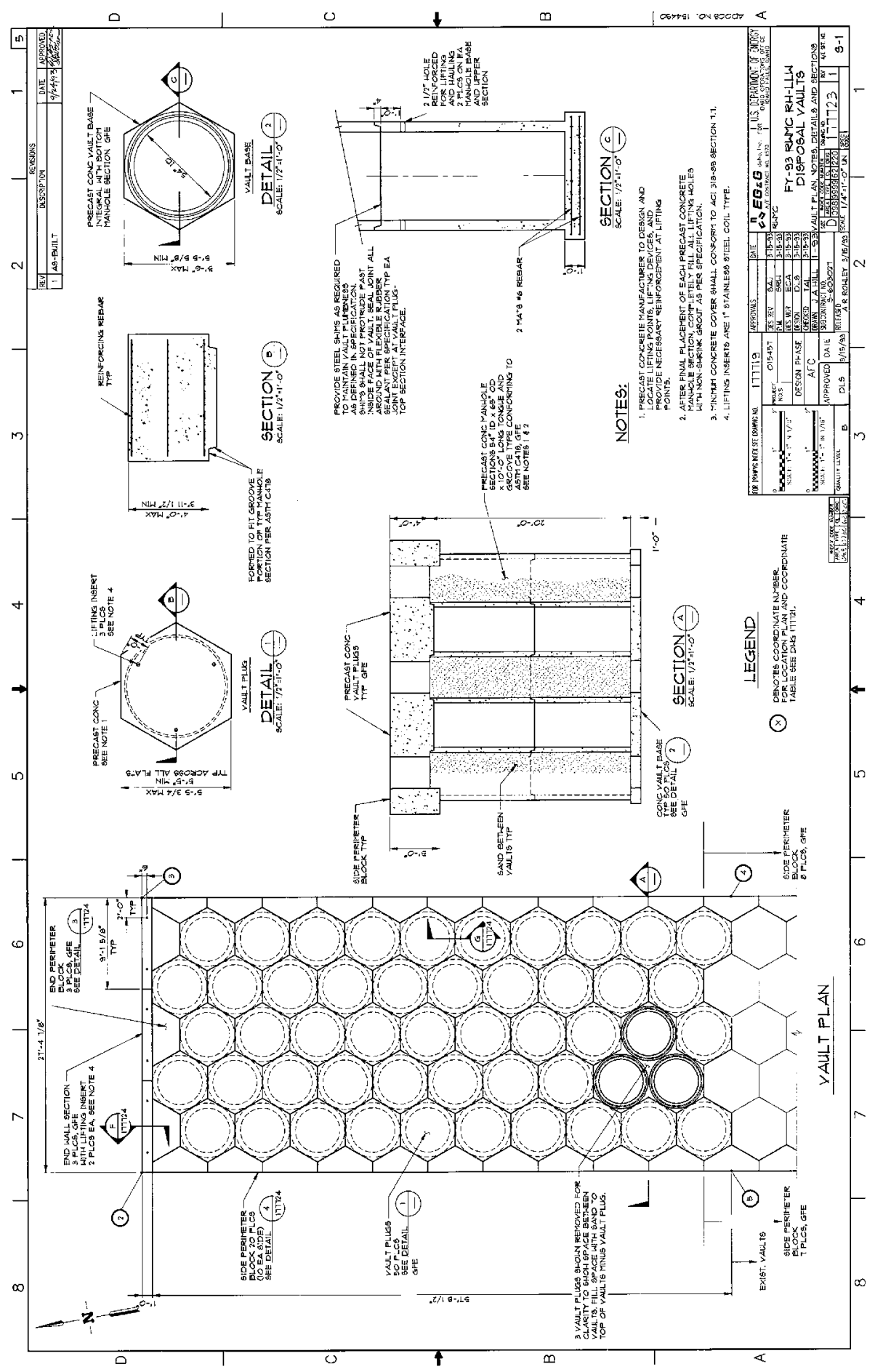




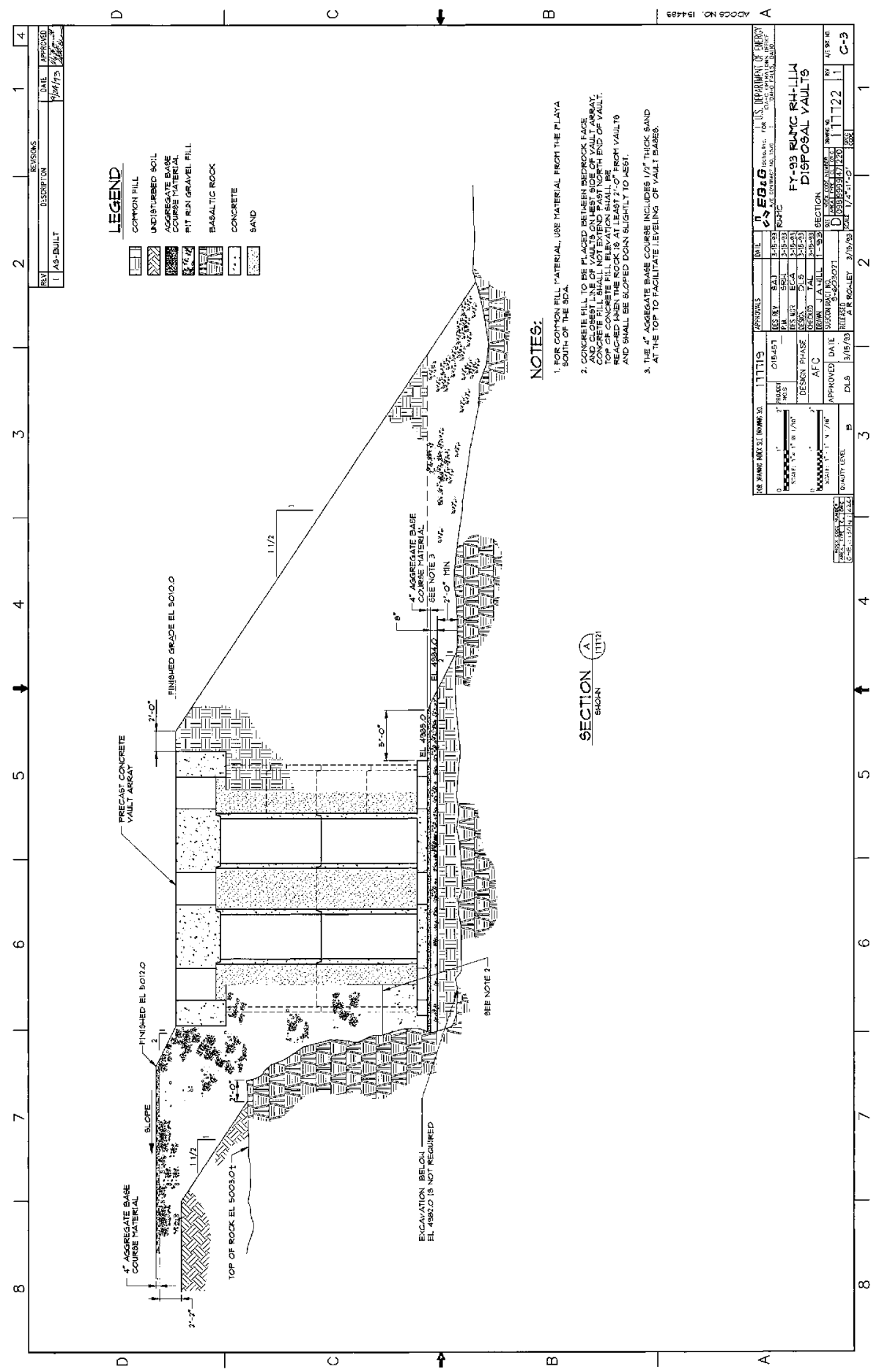




\section{APPENDIX C}

Selected Photos of RWMC SDA Subsidence Features 


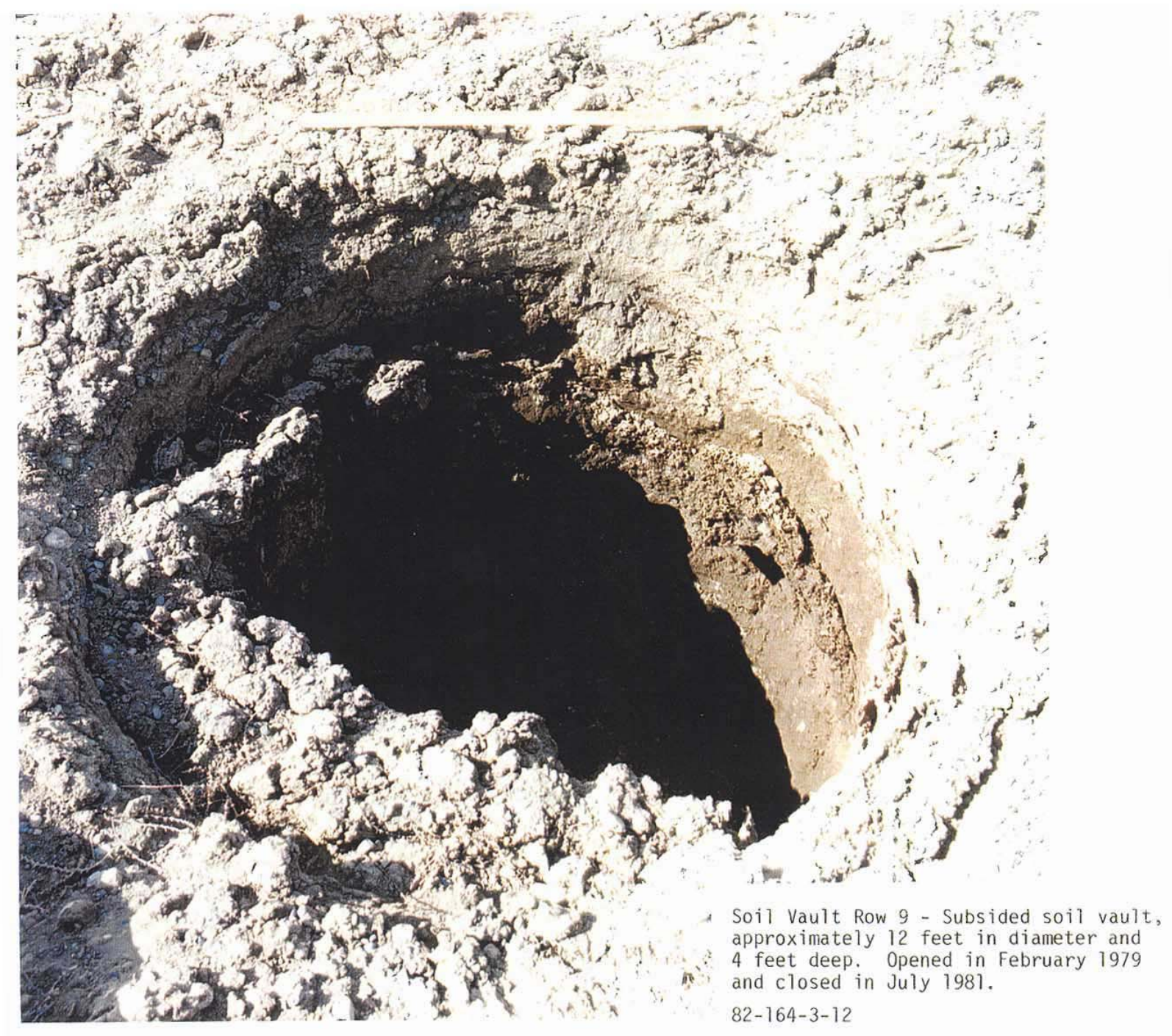




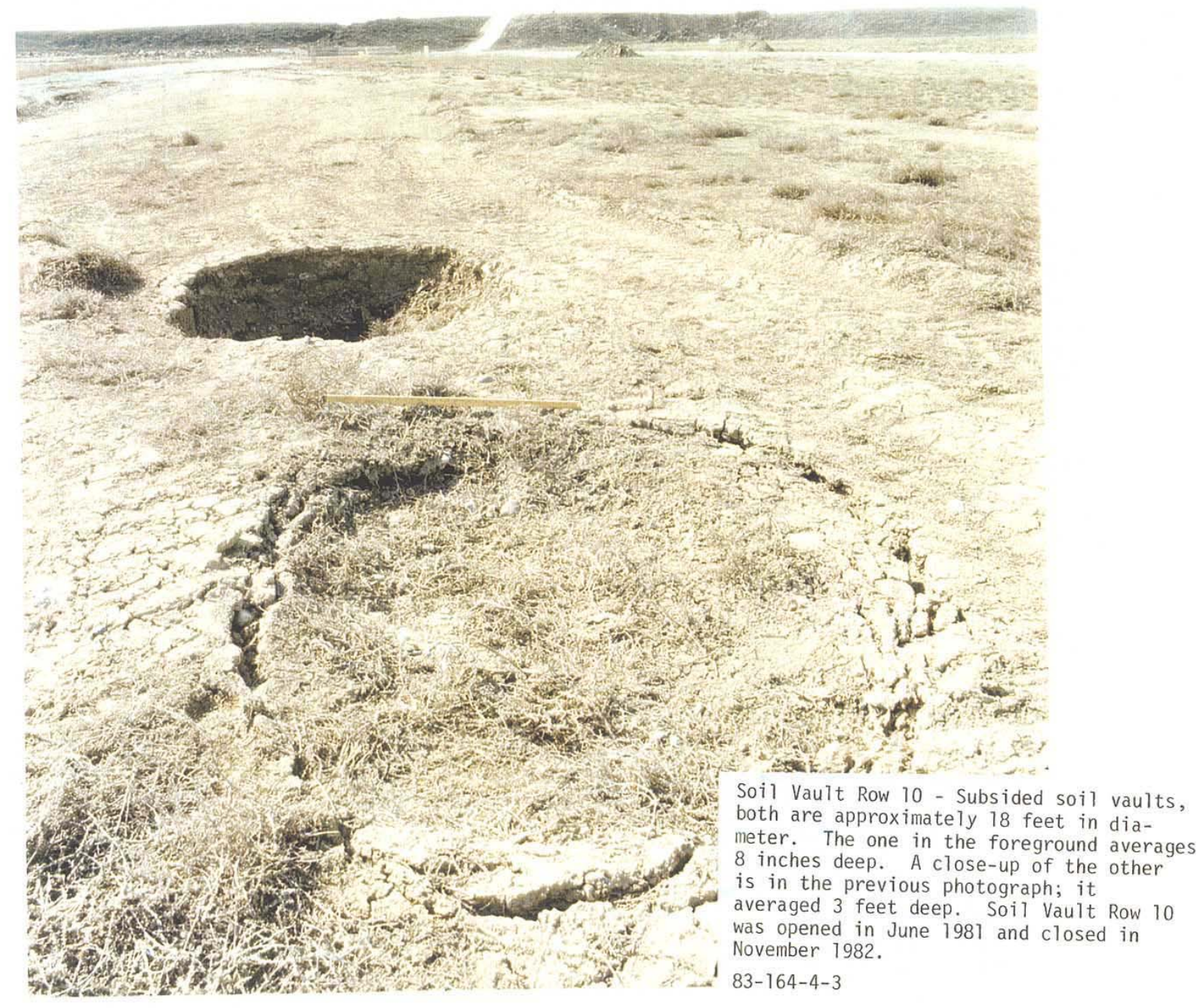




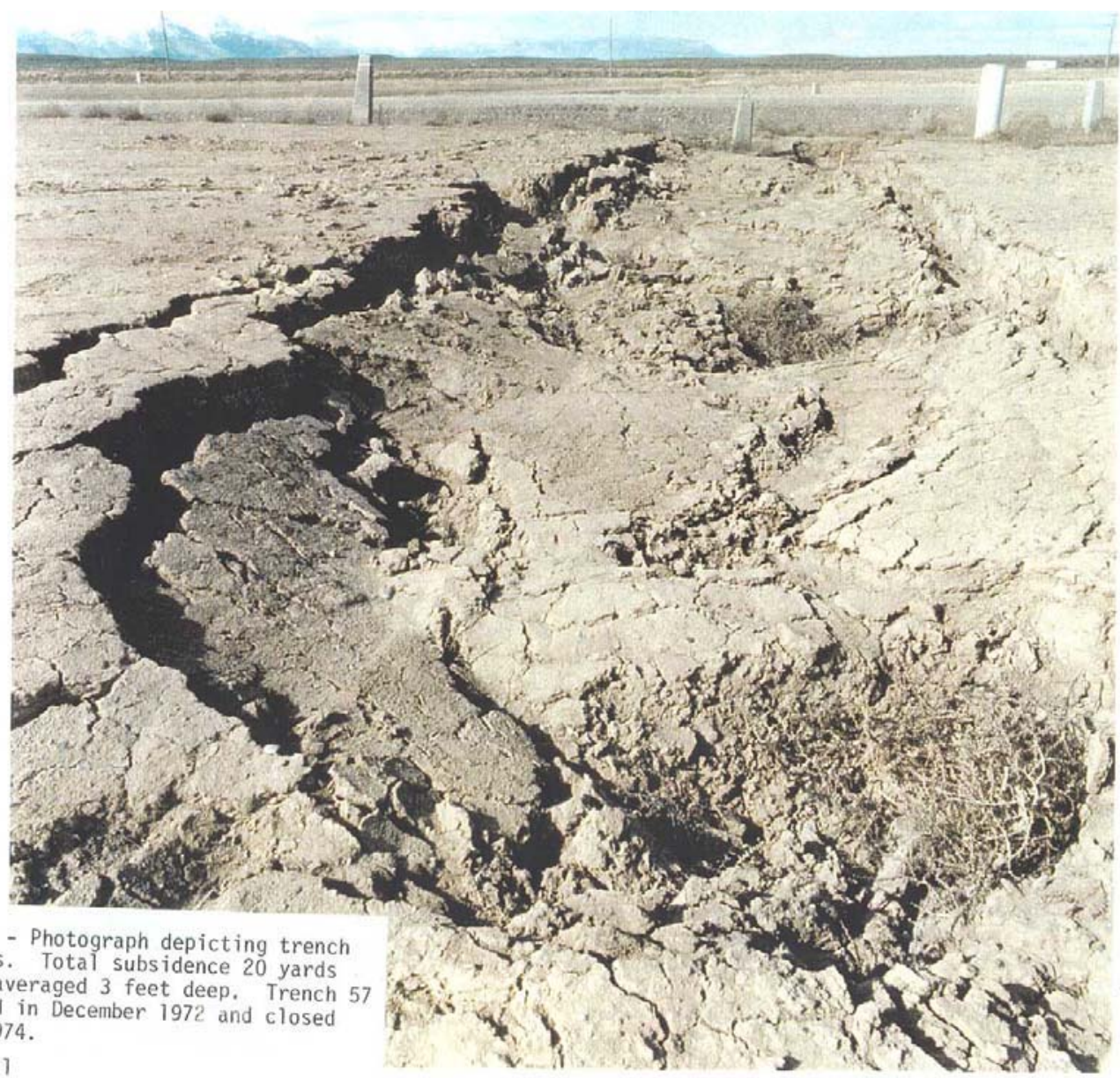




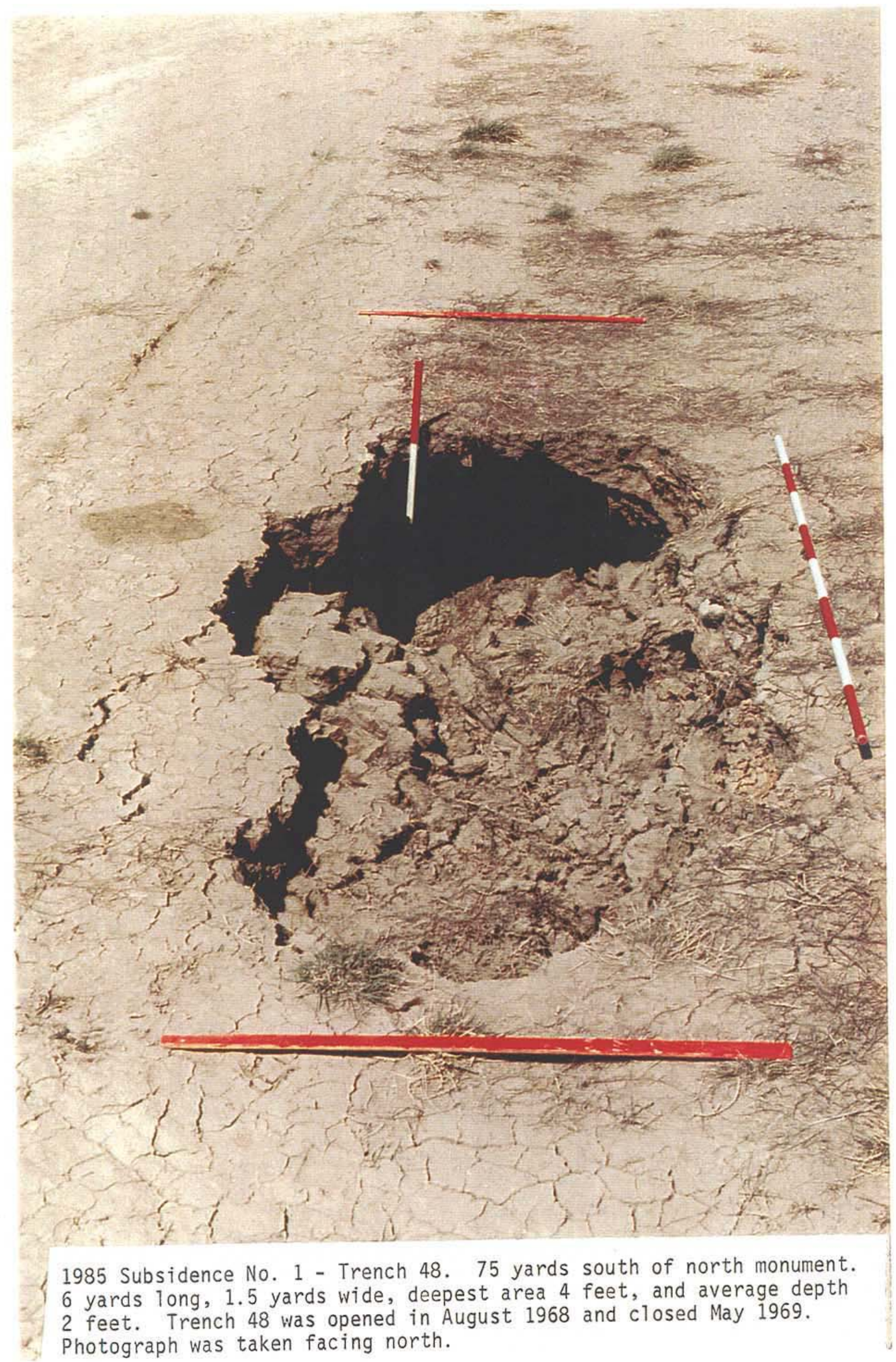




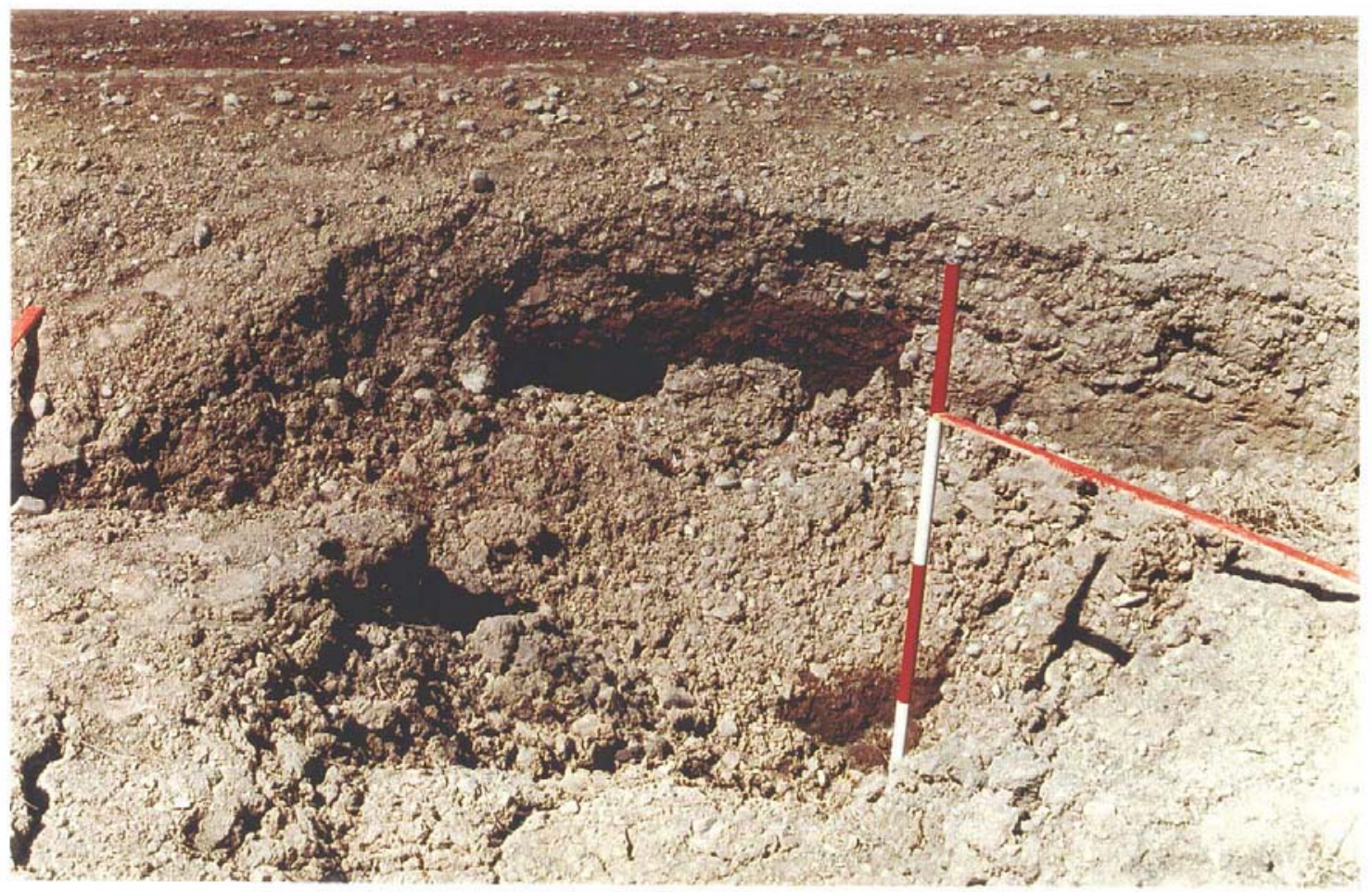

1985 Subsidence No. 2 - Trench 8 deepest area of subsidence. 15 yards west of east monument. 7 yards long,

1 yard wide, deepest area 3 feet, and average depth 1.5 feet. Trench 8 was opened in Decenber 1956 and closed
Hay 1957. Photograph was taken facing north. 


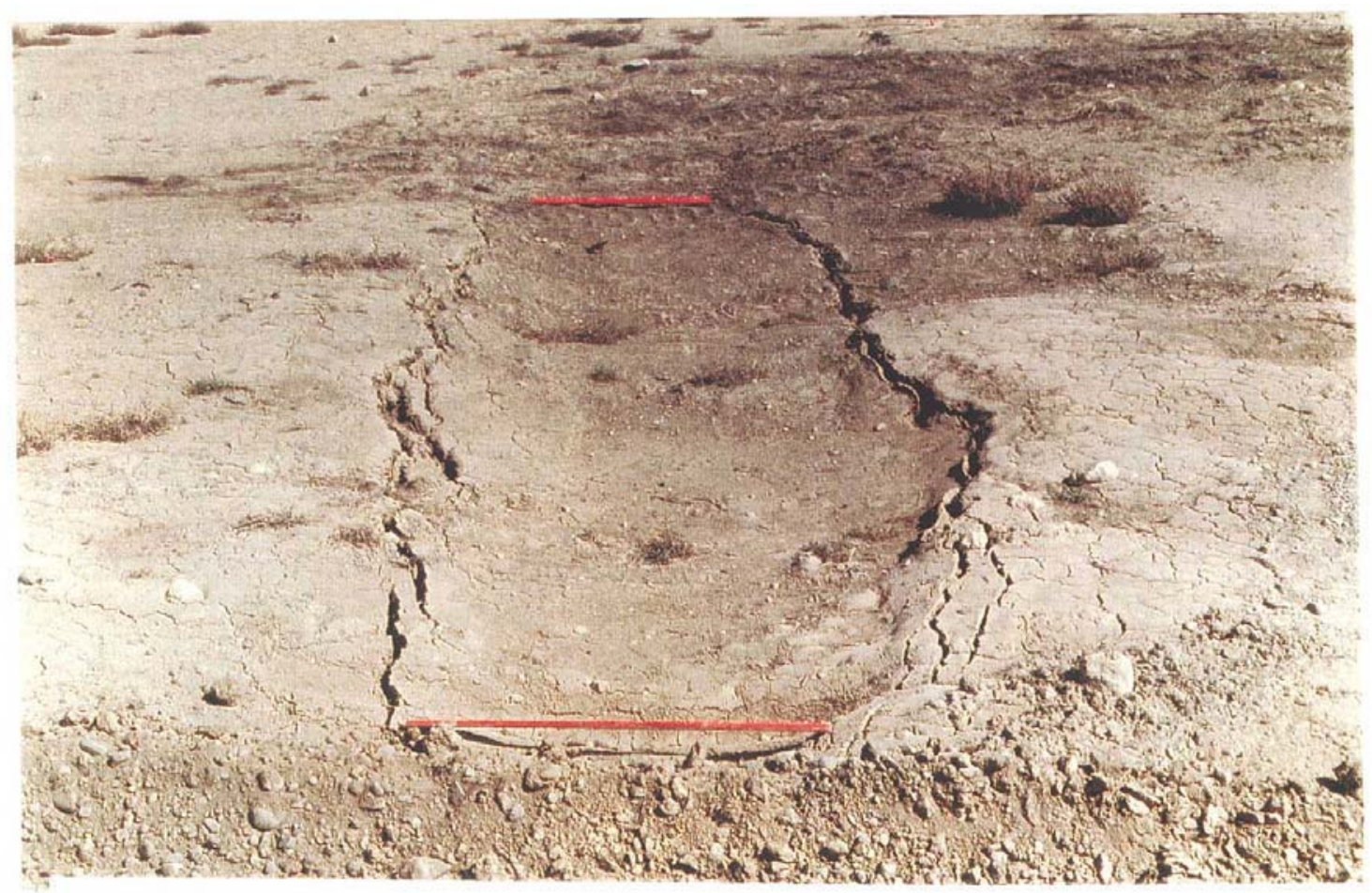

1985 Subsidence No. 9 - Trench 41. 15 yards north of east Trench 31 monument. 10 yards 1ong, 2 yards wide, deepest area 1 foot, and average depth .6 foot. Trench 41 was opened January 1961 and closed 0 ctober 1966. Photograph was taken facing east. 


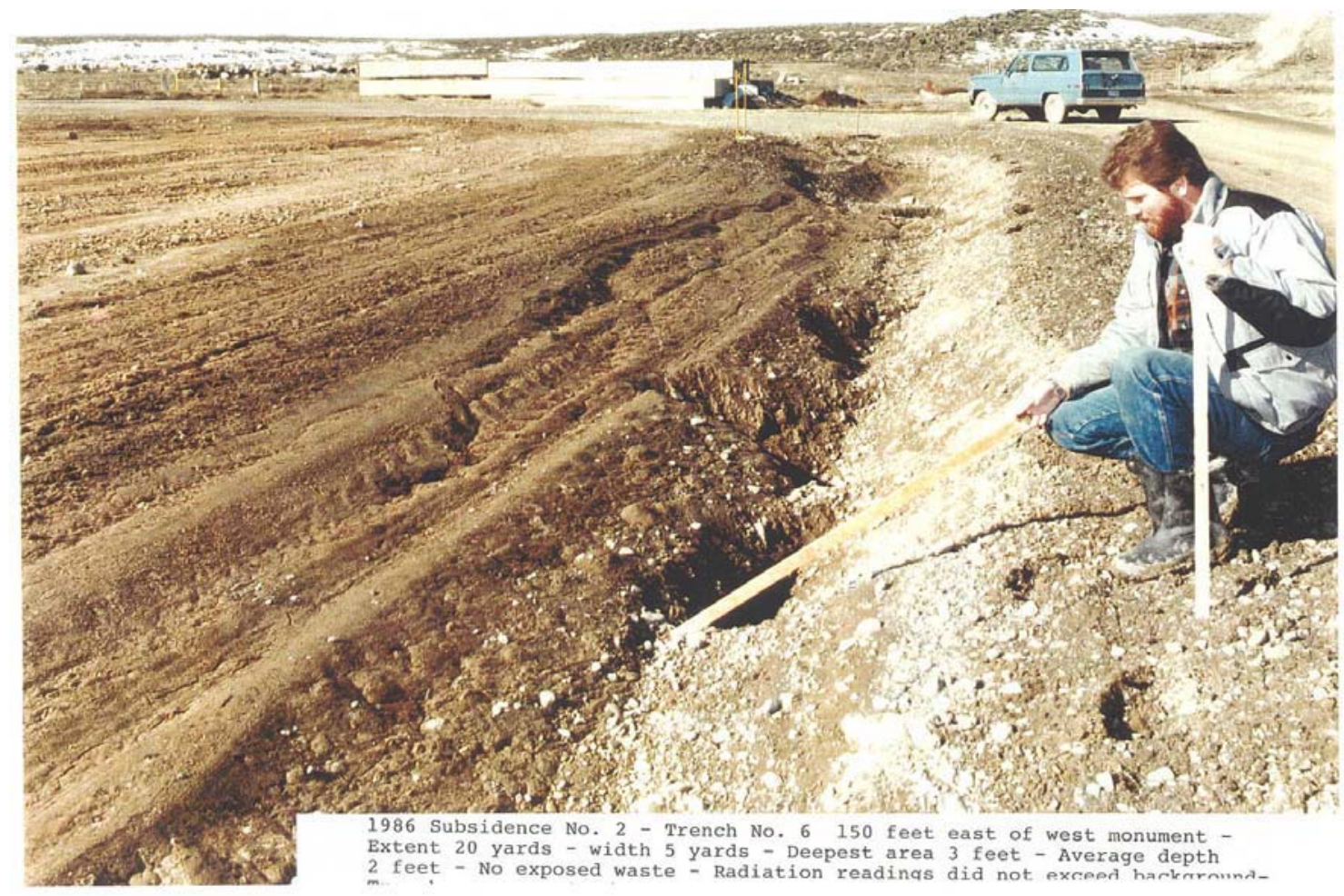




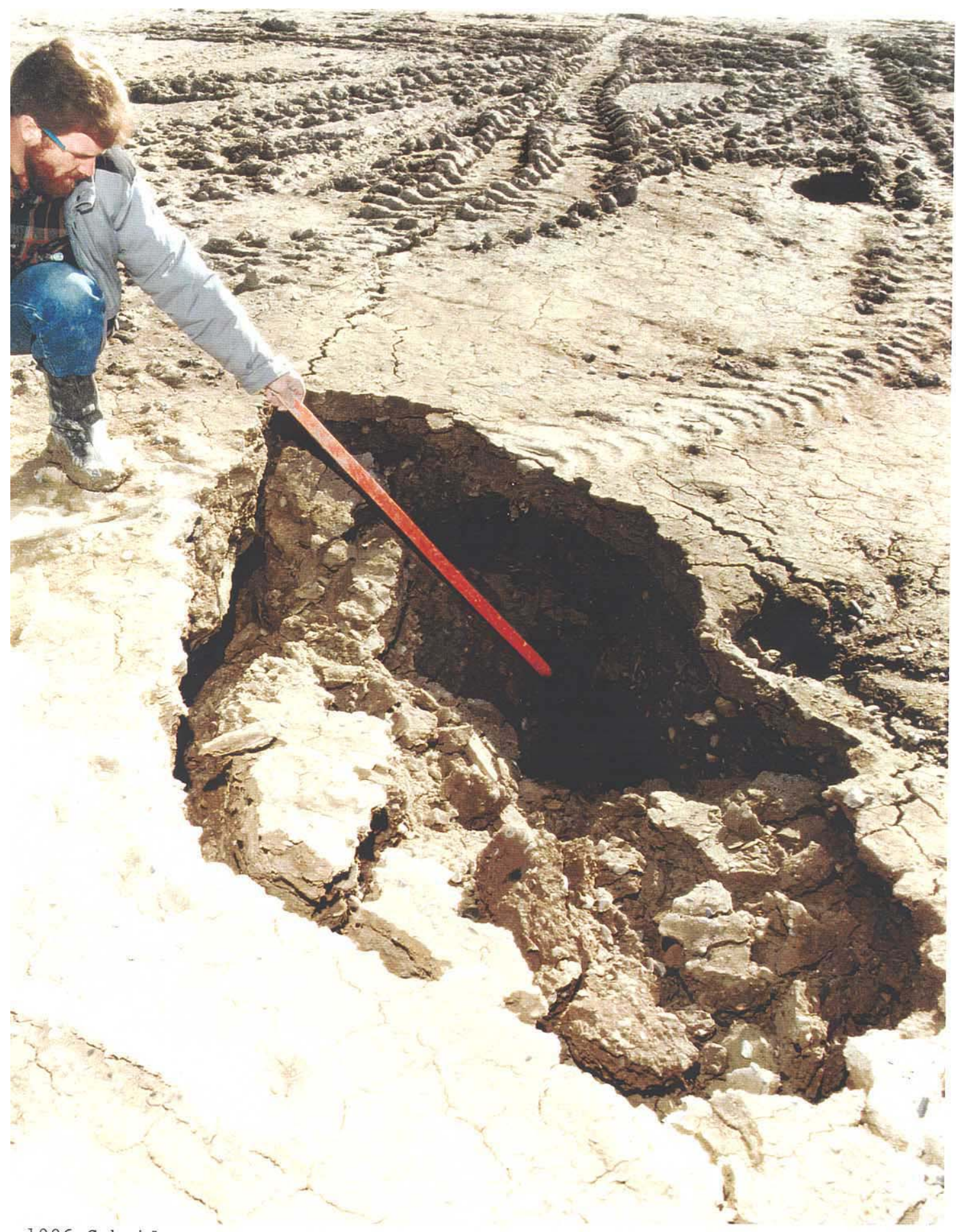

1986 Subsidence No. 4 - Pit No. 17 - Covered area of current open pit

Extent 10 yards - Width 10 yards - Deepest area 1.5 feet average depth

Pit was opened $5 / 5 / 84$ and is currently readings did not exceed background- 


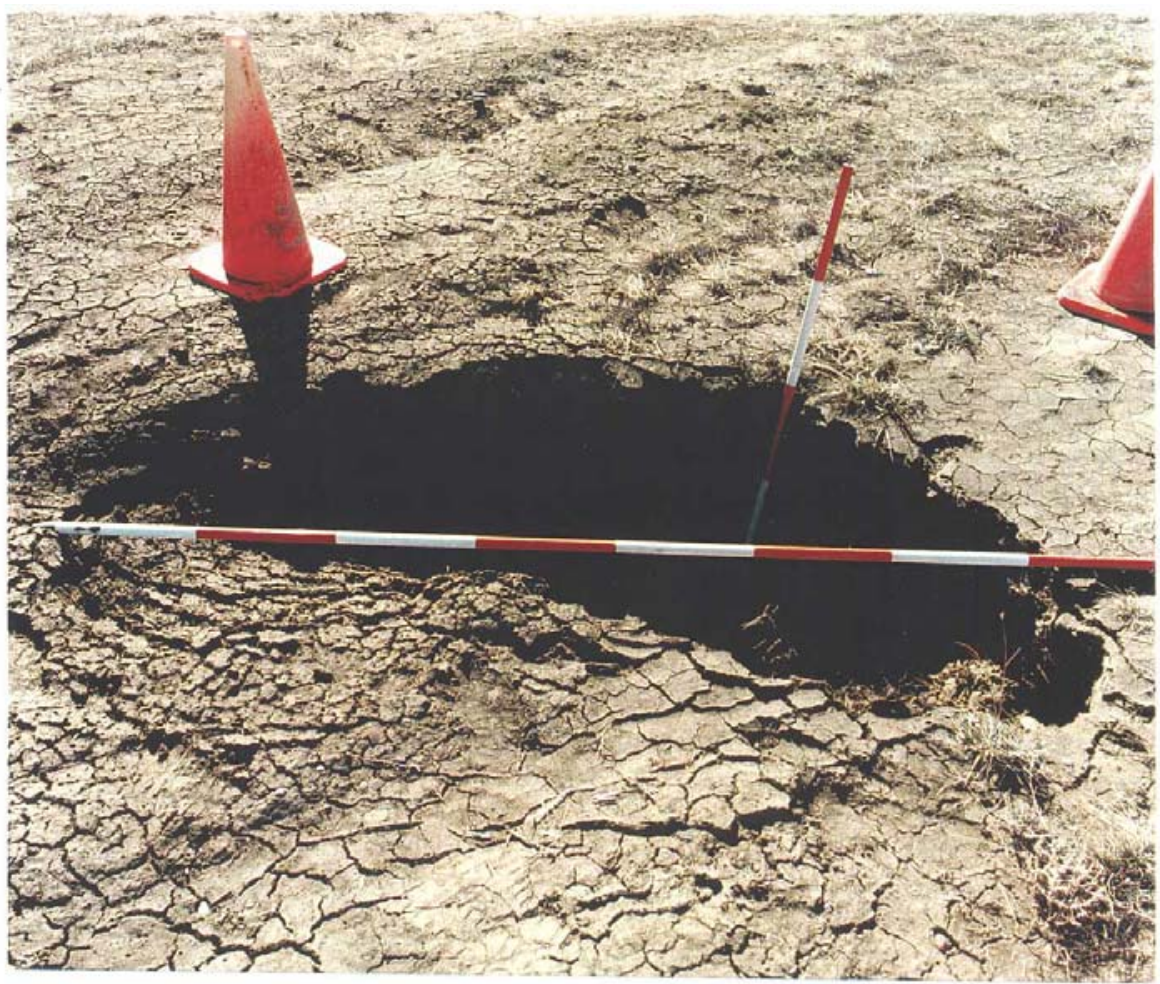

1987 subsidence no.1 along trench 43, 100 yards south of north marker. Subsidence was 2 yards wide and 1

yard long. Average depth was 2 feet and deepest area was 3 feet. No waste was exposed and radiation readings was found in April of 1987 . 
1987 subsidence no. 2 along covered section of pit 17. Subsidence was 4 yards long and 4 yards wide. The average depth was 3 feet and the deepest area was 3.5 feet. No waste was exposed and radiation readings were recorded as background. Pit 17 was opened 5/5/84 and is currently open. Subsidence was found in May of 1987.

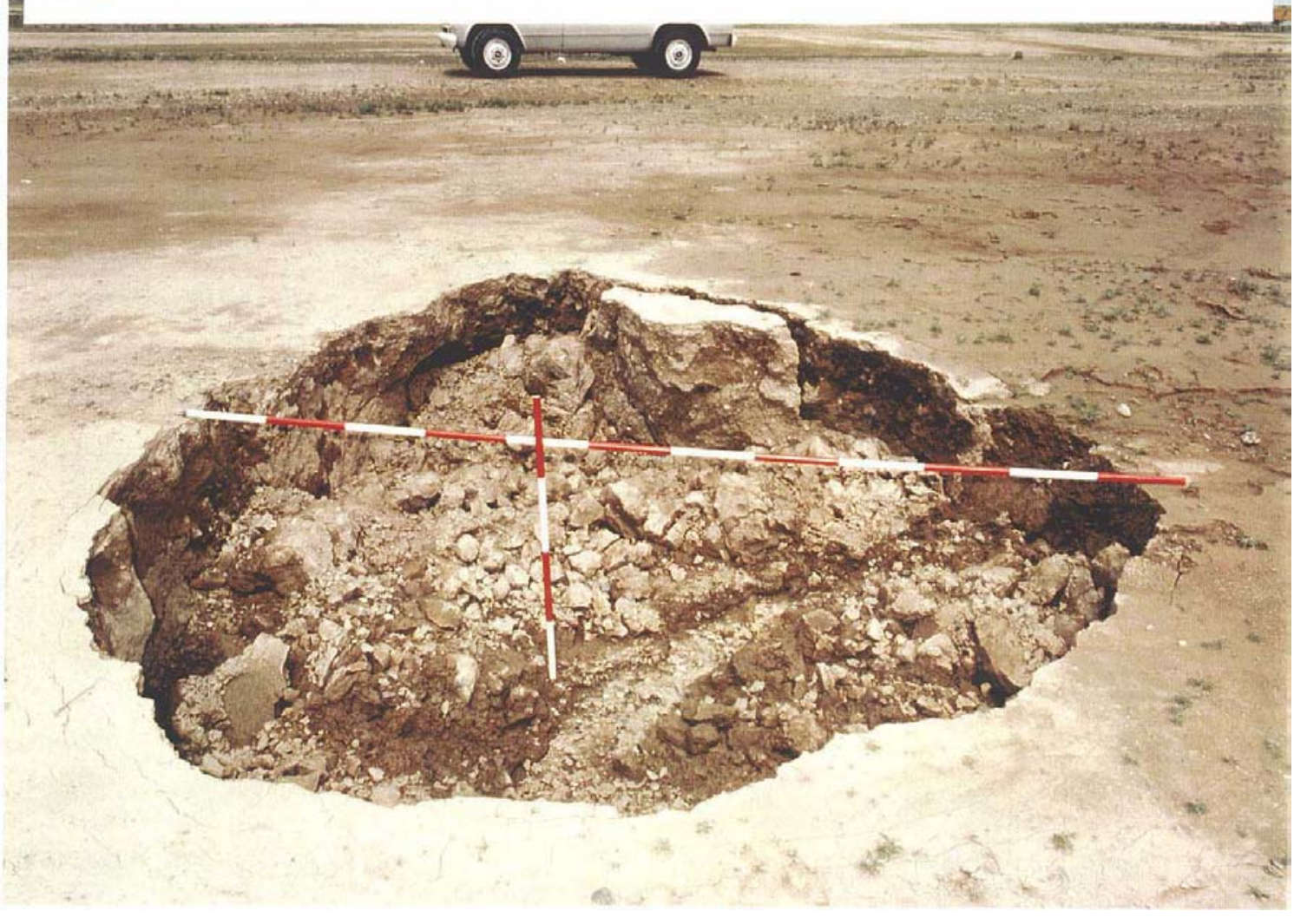

